serie International Automotive Production Networks: How the web comes together

WP-EC 2013-05 Leticia Blázquez and Belén González-Díaz 
Los documentos de trabajo del Ivie ofrecen un avance de los resultados de las investigaciones económicas en curso, con objeto de generar un proceso de discusión previo a su remisión a las revistas científicas. Al publicar este documento de trabajo, el Ivie no asume responsabilidad sobre su contenido.

Ivie working papers offer in advance the results of economic research under way in order to encourage a discussion process before sending them to scientific journals for their final publication. Ivie's decision to publish this working paper does not imply any responsibility for its content.

La Serie EC, coordinada por Matilde Mas, está orientada a la aplicación de distintos instrumentos de análisis al estudio de problemas económicos concretos.

Coordinated by Matilde Mas, the EC Series mainly includes applications of different analytical tools to the study of specific economic problems.

Todos los documentos de trabajo están disponibles de forma gratuita en la web del Ivie http:/ /www.ivie.es, así como las instrucciones para los autores que desean publicar en nuestras series.

Working papers can be downloaded free of charge from the Ivie website http://www.ivie.es, as well as the instructions for authors who are interested in publishing in our series.

Versión: julio 2013 / Version: July 2013

Edita / Published by:

Instituto Valenciano de Investigaciones Económicas, S.A.

C/ Guardia Civil, 22 esc. $21^{\circ}-46020$ Valencia (Spain) 


\title{
International Automotive Production Networks: How the web comes together ${ }^{*}$
}

\author{
Leticia Blázquez and Belén González-Díaz ${ }^{* *}$
}

\begin{abstract}
This paper aims to contribute to the literature on New Economic Geography by providing empirical evidence for the connections between new trade theory and the spatial distribution of economic activities. To do this, we apply Social Network Analysis specifically to the World Automotive Trade Network. We explore the structural features of the auto network for the years 1996 and 2009 using data on trade flows for 172 countries. Our findings suggest that the auto network has become denser, more extensive and more integrated over time, depicting a centerperiphery structure in which regional clusters play a prominent role. In this configuration, strong agglomeration forces generated by companies' desire for large and rich market access with minimum transportation costs are balanced by the search for new high-potential markets.
\end{abstract}

Keywords: World Automotive Trade Networks, New Economic Geography, Social Network Analysis, Parts and Components.

JEL Classification: F10, F14, F15.

\section{Resumen}

El objetivo de este trabajo es contribuir a la literatura basada en la Nueva Geografía Económica mediante la aportación de evidencia empírica sobre la interrelación entre las nuevas teorías del comercio y la distribución espacial de las actividades económicas. Para ello empleamos la metodología de las redes sociales aplicadas concretamente a la red mundial de comercio de la industria del automóvil. Con información estadística de los flujos comerciales de 172 países, se analizan las características estructurales más importantes de la red del automóvil para los años 1996 y 2009. Los resultados ponen de manifiesto que la red de comercio mundial del automóvil se ha hecho más densa, más integrada y más extensa con el paso del tiempo reflejando una clara estructura centro-periferia donde los clusters regionales desempeñan un papel muy relevante. En la configuración de esta red, la importancia de las fuerzas de aglomeración generadas por el deseo de las empresas de acceder a los mercados más importantes con los menores costes de transporte posibles, se ven contrarrestadas por la búsqueda de nuevos mercados con un elevado potencial de crecimiento.

Palabras clave: Red mundial del comercio del automóvil, Nueva Geografía Económica, Análisis de las redes sociales, Partes y componentes.

Clasificación JEL: F10, F14, F15.

\footnotetext{
* The authors thank Rosario Gandoy and Carmen Díaz-Mora for helpful comments and also acknowledge the financial support from the Regional Government of Castilla-La Mancha (PPII10-0154-9251).

** L. Blázquez and B. González-Díaz: University of Castilla-La Mancha (Toledo, Spain). Corresponding author: L. Blázquez, e-mail: Leticia.blazquez@uclm.es.
} 



\section{Introduction}

Trade theories based on New Economic Geography (NEG) have stressed the importance of taking into account the interconnection of regions in the analysis of the spatial distribution of economic activities. They highlight how any change that directly involves only two regions are unlikely to leave the remaining regions unaffected. Additionally, NEG has emphasized that the relative position of the region/country within the whole network of interactions is a key issue faced by firms when choosing where to locate and thus also influences the way they organize their production, management and outsourcing (Krugman, 1993; Thomas, 2002; Fujita and Thisse, 2009).

One of clearest signs of how the complex interactions between countries and regions influence the way companies organize their production and vice-versa has been the emergence of international production networks in most manufacturing sectors. In this sense, the main objective of this paper is to study the structural evolution of the spatial distribution of economic activities for one of the sectors with the highest incidence of global production sharing, the automotive industry, in the light of some of the assumptions and results obtained from New Economic Geography. As alternative to more traditional theoretical models, we will use in this analysis an empirical approach by applying the methodology proposed by the Social Network Analysis.

The extent to which these sharing strategies have been implemented in the auto industry is reflected by the spectacular increase in the world's automotive trade in general during the past decade (from 1996-2009, it grew at a cumulative annual rate of 5.4 percent in nominal terms) and by the particularly high dynamism of its intermediate commodity flows, with an annual cumulative growth rate of 6.2 percent (almost two percentage points more than final goods), increasing its share of the overall world auto trade from 50 to 56 percent. These highly intense international trade flows give us a clear idea of the complexity of the auto industry organization, evidencing the relevance of its network characteristics in its analysis.

According to NEG, the spatial distribution of economic activities can be viewed as the outcome of a complex balance between two types of opposing and mutually reinforcing forces: agglomeration (or centripetal) and dispersion (or centrifugal) forces (Baldwin et al., 2003; Fujita and Thisse, 2009). ${ }^{1}$ In this regard, since the automotive industry can be considered fragmented and to operate under increasing returns to scale in a globally imperfect competitive market, the location of auto companies across space should presumably be explained primarily in terms of the search for privileged access to large, wealthy markets and the desire to relax the competitive pressures imposed by other firms.

\footnotetext{
${ }^{1}$ Two stable spreading equilibria result from the simplest $2 \times 2 \times 2$ model (Krugman, 1991): agglomeration of one of the sectors in one region when transportation costs are very low, and dispersion of this sector in two regions when transportation costs are very high. In this model, Krugman basically adds the interregional mobility factor (workers and firms choose a location) to his new trade theory model (Krugman, 1980). From this stylized model, different and more complex assumptions have been added. For a discussion of the core model and several of its extensions, see, for example, Ottaviano and Thisse (2004).
} 
Therefore, we expect larger economies in terms of population and purchasing power to attract a more than proportional share of auto companies; in other words, for the home market effect to be one the most significant agglomeration forces in the conformation of the auto network. Intermediate transportation costs incurred by the auto industry would lead firms to seek to locate close to their end markets, thus reinforcing the market effect. As a result, we also expect deeper integration within the auto network to actually lead to more regional imbalance in the spatial distribution of the industry and for some degree of economic specialization to arise. Additionally, in a highly fragmented sector like the auto industry, the presence of input-output linkages between firms is expected to be one strong agglomeration force (Krugman and Venables, 1995).

On the other hand, traditional auto markets are fairly mature and the competition between companies in their territories could be labeled as fierce. Therefore, we would expect a dispersion force generated by each firm's desire to avoid market crowding (corresponding to the price effect in spatial competition) to emerge. Fostered by this dispersion force, some firms would relocate from the traditional core to the periphery, yielding a bell-shaped curve of spatial development à la Kuznets.

In order to evaluate the extent to which the evolution of the auto industry structure responds to these assumptions set by the NEG, we will apply Social Network Analysis tools and graph theory to the world trade web rather than the traditional general equilibrium models applied by the NEG. The reason is that, although the contribution of NEG to introducing spatial factors into rigorous models is unquestionable, its own precursors have pointed out that these models are too stylized and simple to adequately represent the real economic geography and thus become relevant from a policy-making standpoint (Krugman, 2001, p.59).

In the analysis of these cross-border production blocks, multiple factors should be taken into account. It is not only a question of intensifying the openness of countries, but also of developing networks of direct and indirect relations between individuals, companies and countries at a distance from each other (Arribas-Pérez and Tortosa-Ausina, 2009). Network approach is an appropriate method for studying such issues as it provides a methodology that enables us to measure the nature of these relations and how and to which extent and they evolve over time in ways that other measures do not capture. By applying network analysis to international trade, we can complement other empirical analyses of trade that put countries' characteristics at the forefront (e.g. the gravity model of international trade) since it places more emphasis on the relationship between units in the graph and on the structure of the system itself than on the units' attributes, which are generally left in the background.

Although these techniques have not been very extensively used in economics to date, the approach is not new in international economics (see, for instance, the recent paper by Chinazzi et al., 2013) and specifically in trade analysis. Recent examples include Garlaschelli and Loffredo (2005), Kali and Reyes (2007), Kali et al. (2007), Arribas et al. (2009), Fagiolo et al. (2008), Fagiolo (2010), and De Benedictis and Tajoli (2011). All of these studies focus 
on analyzing the world trade network and accurately analyze the properties of the system in terms of trade flows, partners and links. Most of them suggest that there is strong heterogeneity between countries, with nations playing very different roles in the network structure, but there is only a very limited effort in these studies to explain these findings on the basis of trade or location theories. Moreover, none of them analyzes specifically the characteristics of sharing production networks nor considers the differentiated features of sectors which use these strategies as we do in this paper by focusing on one specific sector. The structural characteristics of the world automotive trade network have been analyzed in several meritorious studies (e.g., Humphrey and Memedovic, 2003; Sturgeon et al. 2008, 2009; Amighini and Gorgoni, 2010; Sturgeon and Van Bieserbroeck, 2010, 2011). However, most of these papers do not offer an empirical analysis with a solid analytical framework that makes it possible to find stronger affinities with trade theories and international economics. In this sense, this paper complements these more descriptive contributions.

The article is organized as follows. In section 2, we briefly explain the main network analysis tools and the data source used in the research. Section 3 describes the evolution of structural features of the world automotive trade network and analyzes the agglomeration and dispersion forces behind this evolution. Section 4 offers some concluding remarks.

\section{Social Network Analysis and Data}

Social Network Analysis is based on mathematical graph theory. In the graph representing the world automotive trade network (WATN, hereafter), the vertices of the network represent the trading countries and the lines represent the trade flows between any two partners: exports and imports. We consider the WATN from two complementary standpoints. First, we build a weighted network where each directed link represents the value of export from the country of origin (the exporter) to the target country (the importer) as reported by the importer ${ }^{2}$. While we are interested in comparing the structure of the WATN at two different moments in time, we also define rescaled weights relative to the total yearly trade flows. ${ }^{3}$ In this way, trend effects are eliminated and we obtain adimensional weights that are automatically deflated, allowing for consistent comparisons across different years and commodity types (Squartini et al., 2011b). Additionally, we have also explored the properties of the binary projection of the weighted generic matrix by analyzing the mere presence or absence of a trade relationship between two countries.

The sequence of binary and weighted matrices fully describes the within-sample dynamics of the WATN, and its main characteristics can be summarized by topological

\footnotetext{
${ }^{2}$ The directed nature of the WATN is based in the calculus of the symmetry index, $S$, proposed in Fagiolo (2006). Since the asymmetric patterns have been statistically identified, a directed analysis of the network is necessary.

${ }^{3} \mathrm{~W}_{\mathrm{ij}}^{\prime}(\mathrm{t}) \equiv \frac{\mathrm{W}_{\mathrm{ij}}(\mathrm{t})}{\mathrm{W}_{\text {tot }}(\mathrm{t})}$ where $w_{i j}(t)$ are exports from country $i$ to country $j$ in period $t$ and $w_{\text {tot }}(t) \equiv \Sigma_{i} \Sigma_{j \neq i} w_{i j}(t)$.
} 
measures and paths. ${ }^{4}$ To this extent, we have calculated both aggregate and node-specific network statistics. The aggregate topological measures provide evidence for the structural properties of the whole network. In this vein, the number of partners and the interaction intensity of countries, as well as the way these patterns have changed over time, will give a clear idea about the evolution of the connectivity of countries in the WATN. The widest measure of the connectivity or cohesiveness of a network is its density (i.e. the fraction of all possible links that are actually present). Additionally, we have analyzed the shape of the network by measuring the extent to which it has (or has not) a center. The degree centralization index $-C_{D}$ - (i.e. the variation in the number of trade links that a given country has established divided by the maximum degree of variation possible) provides this information. And the group random betweenness centralization index $-B C N-$ describes and compares different networks with respect to the heterogeneity of the role of their members as intermediaries in the network.

Together with these aggregate measures, node-specific network statistics consider individual countries' positions within the WATN. We thus determine how many trade links a country has established (i.e. node degree measures), distinguishing between the number of countries that the country imports from (indegree) and the number of countries that receive exports from this partner (outdegree). Correspondingly, we can assess the weights associated with the trade links maintained by each country (i.e. node strength measures). The larger the node strength of a country, the higher the intensity of the interactions it mediates. In this sense, it is also interesting to identify authorities and hubs within the network. Using the HITS algorithm developed by Kleinberg (1999), we can determine which countries are (via strongly weighted in-links) more pointed-to by hubs, becoming authorities; and which countries point (via strongly weighted out-links) to more authorities, becoming hubs. ${ }^{5}$

Furthermore, in assessing the centrality of countries within the network, we examine their closeness centrality index $-C L-$ that measures how easily a country can trade with all the others taking into account the geodesic distances between them; and their random betweenness centrality index that reveals how important a country is as an intermediary in the network. The binary version of the latter index $-R W B C$ - would indicate the extent to which a country is crucial for the integration of the network whereas its weighted version $-R W W B C$ captures the effects of the magnitude of the relationships that each node has with its partners, as well as the strength of the node in question. ${ }^{6}$

\footnotetext{
${ }^{4}$ A more extensive and detailed description of the topological measures included in this section can be found in the seminal book by Wasserman and Faust (1994). The corresponding analytical description of this section is presented in Table A3 of the Statistical Appendix.

${ }^{5}$ Note that an authoritative country may also be a hub, and vice versa. It is also important to be aware that HITS hub/authority rankings tend to be strongly correlated with the out-/in-degrees of the corresponding nodes (Benzi et al, 2013).

${ }^{6}$ In particular, we use in this study the Random-walk betweenness centrality index proposed by Newman (2005) and Fisher and Vega-Redondo (2006).
} 
Another important feature of network structure concerns the extent to which a given country is clustered (i.e. how much the partners of a country are themselves partners). In order to identify clusters of countries that are closely connected insofar as they all share a particular minimum degree within the cluster, we apply the so-called $k$-cores analysis. ${ }^{7}$

These first-order indicators indicate the extent to which the WATN shows a coreperiphery structure; i.e. to which the agglomeration forces prevail in the conformation of the network. Additionally, we can analyze second-order relations, which indicate how and how much each country's partners are themselves connected within the network. In doing so, we can evaluate the influence of dispersion forces on the network shape and its evolution.

To do this, we have computed the average nearest-neighbor degree (ANND), i.e. the average number of partners of the neighbors (partners) of a country. We have also calculated how much the partners of a node are themselves characterized by high strength by computing the weighted average of nearest-neighbor node degrees (WANND) and the arithmetic average of nearest neighbor strengths (ANNS). Note that in both the binary and the weighted network we can consider separately the different directional trade relations, i.e. the trade relations between the country considered and its partners as well as the relationships of the trade partners of the country analyzed.

The main data source employed in the analysis has been the United Nations COMTRADE Database. The trade data used is bilateral exports/imports as reported by the importing country and measured in nominal U.S. dollars. ${ }^{8}$ Following the HS1996 categories identified by Türkcan (2009) and the SITC Rev.2 categories recognized by Kaminski and Ng (2001) for auto $\mathrm{P} \& \mathrm{C}$, we provide a more extensive and complete code list for automotive final goods and their P\&C corresponding to HS1992 (Table A2 in the Statistical Appendix). With these data, we have created separate trade matrixes between countries for the exchange of automotive final goods and their corresponding parts and components (henceforth, P\&C). The matrixes include 172 countries and have been constructed for the years 1996 and 2009. ${ }^{9}$

The use of $\mathrm{P} \& \mathrm{C}$ trade as a suitable proxy for participation in international production networks is commonplace. Because of their intermediate nature, $\mathrm{P} \& \mathrm{C}$ foreign exchanges must necessarily be targeted at assembly in the importer country or for incorporation into a further stage of production in another economy (except spare parts).

Furthermore, although in capital and technology-intensive industries such as this, the production of $\mathrm{P} \& \mathrm{C}$ is considered to be relatively capital-intensive while their assembly is relatively more labor-intensive (Kim, 2002; Athukorala, 2009), there are considerable

\footnotetext{
${ }^{7} \mathrm{~A} k$-core is a maximal subnetwork in which each vertex has at least degree $k$. It therefore identifies relatively dense subnetworks and thus cohesive subgroups within the whole network.

${ }^{8}$ We restricted our analysis to those import flows whose values are higher than or equal to 3 per cent of the country's total imports of the specific commodity considered.

${ }^{9}$ The selection of the number of countries was based on the availability of data for both of the periods analyzed. See Table A1 in the Statistical Appendix.
} 
differences between automotive $\mathrm{P} \& \mathrm{C}$ in terms of factorial intensity. These differences will, in turn, influence transportation costs, transaction cost and the extent to which scale economies can be exploited. These factors are very much taken into account by auto companies in their outsourcing and location decisions. It is interesting, then, to explore whether the structural transformations and changes in countries' specialization also depends on the factorial intensity of auto P\&C. In order to do this and following Peneder (1999), we have differentiated four $\mathrm{P} \& \mathrm{C}$ subnetworks according to their factorial intensity: mainstream-driven, capital intensive-driven, technology-driven and labor-intensive-driven. ${ }^{10}$

The final assembly tasks should also be considered in the analysis for two main reasons. Firstly, from the standpoint of international production networks, a study of the final automotive goods export network is particularly relevant, since in doing so we are considering those countries operating in the last stages of the value chain, i.e. in assembly of P\&C into the final goods and their subsequent export. Secondly, in recent years there has been a notable expansion of network activities from pure production and assembly of $\mathrm{P} \& \mathrm{C}$ to final assembly (Athukorala, 2011).

\section{The International Automotive Production Network}

\subsection{First-order indicators: Agglomeration forces}

The aggregate network statistics reveal that the $\mathrm{P} \& \mathrm{C}$ network has become denser and more extensive over time since countries have, on average, increased the number of partners with which they have trade relations (Table 1). However, the results for centrality measures permit the argument that the auto $\mathrm{P} \& \mathrm{C}$ network has maintained a centre-periphery structure in terms of connectivity and intensity. The higher degree centralization index would suggest unevenly increasing integration within the network. And the increasing betweenness centralization indexes, mainly the weighted index, would indicate the growing importance of hubs in the WATN.

The pattern of heterogeneity between countries within the WANT is clearly visible in Figure 1. We can appreciate a small group of highly connected countries in the centre having trade relations with the vast majority of the other countries, and with most countries having a very small number of partners that, in particular, only have trade relations with those central countries. Nevertheless, it should be noted that only the P\&C export network exhibits a clear and increasingly star-shaped structure, whereas the $\mathrm{P} \& \mathrm{C}$ import network looks rather like a regular graph (Figures 2). It is also remarkable to note that, according to the closeness centrality index, distances between trading economies seem to be shortened insofar as more

\footnotetext{
${ }^{10}$ Peneder (1999) identified five groups rather than four. The fifth group refers to marketing-driven P\&C. Since, in the case of the automotive industry, this category includes only two items which account for only $0.3 \%$ of the total trade in automotive $\mathrm{P} \& \mathrm{C}$ we have decided not to analyze this category separately. The mainstream-driven category refers to those items in which input combinations do not share a major reliance on any particular input factor.
} 
Table 1. Topological Measures of the World Automotive Trade Network ${ }^{\mathrm{a}}$

\begin{tabular}{|c|c|c|c|c|c|c|c|c|c|}
\hline \multirow{2}{*}{ Binary Network Indexes } & \multicolumn{2}{|c|}{$\mathbf{P \& C}$} & \multicolumn{2}{|c|}{ Final Goods } & \multirow{2}{*}{ Weighted Network Indexes } & \multicolumn{2}{|c|}{$\mathbf{P \& C}$} & \multicolumn{2}{|c|}{ Final Goods } \\
\hline & 1996 & 2009 & 1996 & 2009 & & 1996 & 2009 & 1996 & 2009 \\
\hline Arcs & 1129 & 1257 & 1018 & 1115 & & 1129 & 1257 & 1018 & 1115 \\
\hline Density & 0.038 & 0.042 & 0.035 & 0.037 & & & & & \\
\hline Average Node Degree (number of lines) & 13.128 & 14.616 & 11.837 & 12.965 & Average Node Strength & 1.156 & 1.146 & 1.153 & 1.161 \\
\hline Indegree/Outdegree (Average) & 6.564 & 7.308 & 5.918 & 6.482 & Instrength/Outstrength (Average) & 0.578 & 0.582 & 0.576 & 0.580 \\
\hline Average Nearest-Neighbor Degree (ANND) & 66.94 & 68.16 & 73.398 & 67.399 & Average Nearest-Neighbor Strength (ANNS) & 10.239 & 8.362 & 11.3777 & 9.272 \\
\hline Degree Centralization & 0.691 & 0.861 & 0.838 & 0.781 & & & & & \\
\hline Indegree Centralization & 0.032 & 0.028 & 0.030 & 0.038 & & & & & \\
\hline Outdegree Centralization & 0.722 & 0.894 & 0.866 & 0.811 & & & & & \\
\hline Closeness Centrality & 0.487 & 0.509 & 0.503 & 0.510 & & & & & \\
\hline Input Closeness Centrality & 0.087 & 0.084 & 0.060 & 0.072 & & & & & \\
\hline Output Closeness Centrality & 0.093 & 0.092 & 0.062 & 0.078 & & & & & \\
\hline Random Walk Betweenness Centrality (RWBC) & 0.037 & 0.042 & 0.039 & 0.055 & Random Walk Weighted Betweenness Centrality (RWWBC) & 0.572 & 3.932 & 2.774 & 3.357 \\
\hline Random Walk Betweenness Centralization & 0.459 & 0.529 & 0.573 & 0.726 & Random Walk Weighted Betweenness Centralization & 19.845 & 166.683 & 184.516 & 181.009 \\
\hline Export k-cores & $8(\mathrm{k}=4)^{*}$ & $12(\mathrm{k}=4)^{* *}$ & $7(\mathrm{k}=4)^{\bullet * *}$ & $7(\mathrm{k}=5)^{\bullet \cdots}$ & & & & & \\
\hline
\end{tabular}

a There are statistically significant differences (5\% significance) between the measures for P\&C and Final Goods in the Indegree's indicators for 1996 and 2009 and the ANND for 1996 , while for the rest (Outdegree, Degree, Instrength, Outstrength, Node Strength, ANND for 2009, ANNS, RWBC) no statistically significant differences are found between the averages for P\&C and Final Goods.

- The highest core of the P\&C export network was formed by Belgium-Luxemburg, France, Germany, Italy, Spain, the United Kingdom, Japan and USA. "^ France, Germany, Italy, Spain, the United Kingdom, Japan, USA, China, Korea, Czech Republic, Hungary and Poland.

$* *$ Belgium-Luxembourg, France, Germany, Italy, Japan, Spain, United Kingdom.

Source: authors' calculation, based on UN COMTRADE. 
direct trading relations have emerged. Therefore, we can say that the trade integration of the $\mathrm{P} \& \mathrm{C}$ auto network has increased over time.

Figure 1. Automotive P\&C. Outdegree Network (2009)

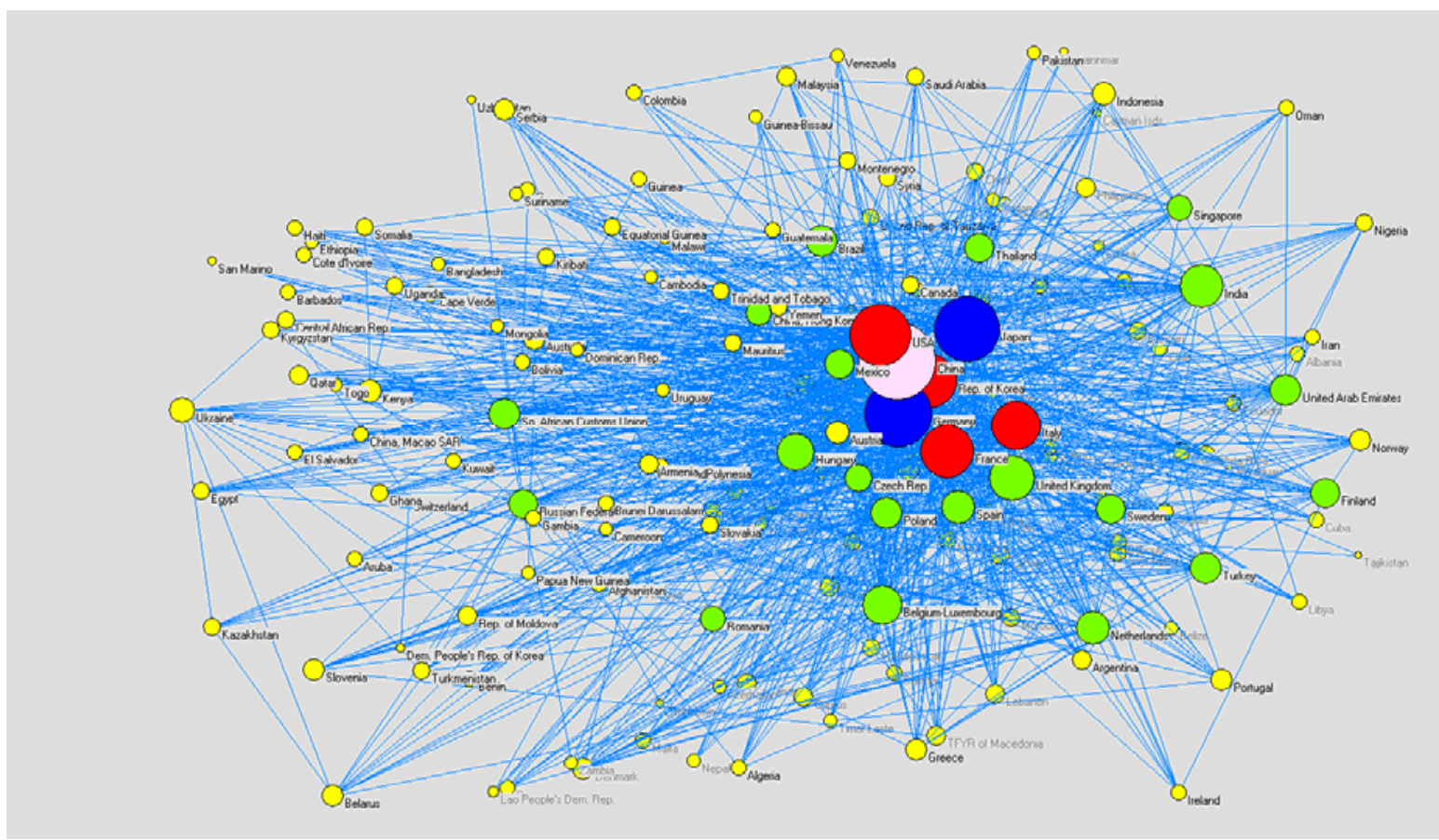

Source: authors' calculation, based on UN COMTRADE using PAJEK. The size of vertices is related to their outdegrees

Figure 2. Automotive P\&C. Indegree Network (2009)

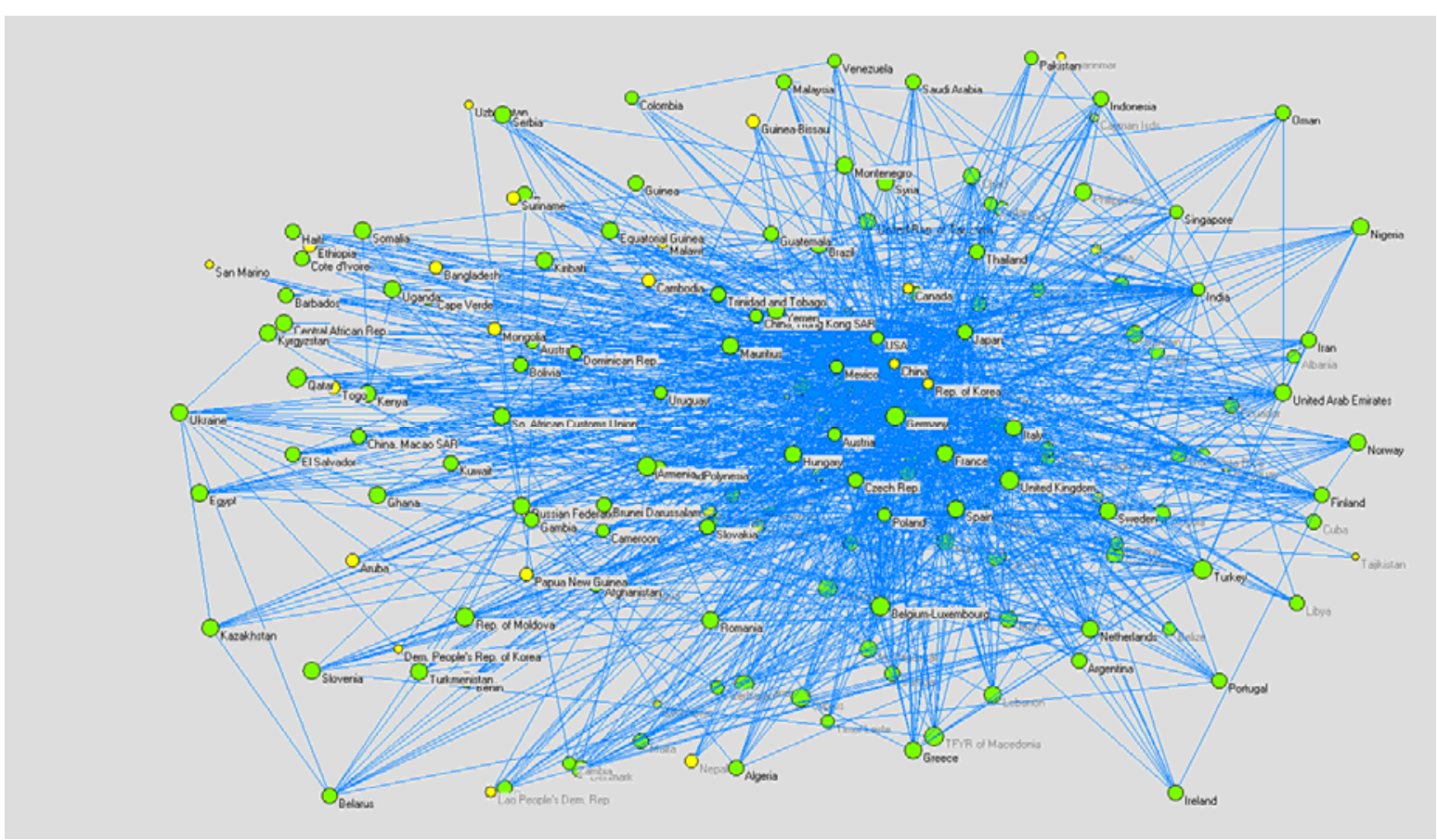

Source: authors' calculation, based on UN COMTRADE using PAJEK. The size of vertices is related to their indegrees 
Additionally, Figure 3 shows that highly connected and integrated countries are also the most (on average) intensely connected It is interesting to observe how the variability in average strength is fairly high for those countries with a relatively low degree, while from a certain degree onwards, countries are able to maintain intense trade relationships. Moreover, we observe that not only are there few countries with a higher number of links, but there are even fewer that are intensely connected. We have also detected that those few countries with increasingly intense relationships are also the ones that play a more prominent role as intermediaries within the network (Figure 4) and that these gatekeeper countries have intensified their role over time.

Figure 3. Correlation between Degree and Average Node Strength for P\&C WATN (1996 and 2009)
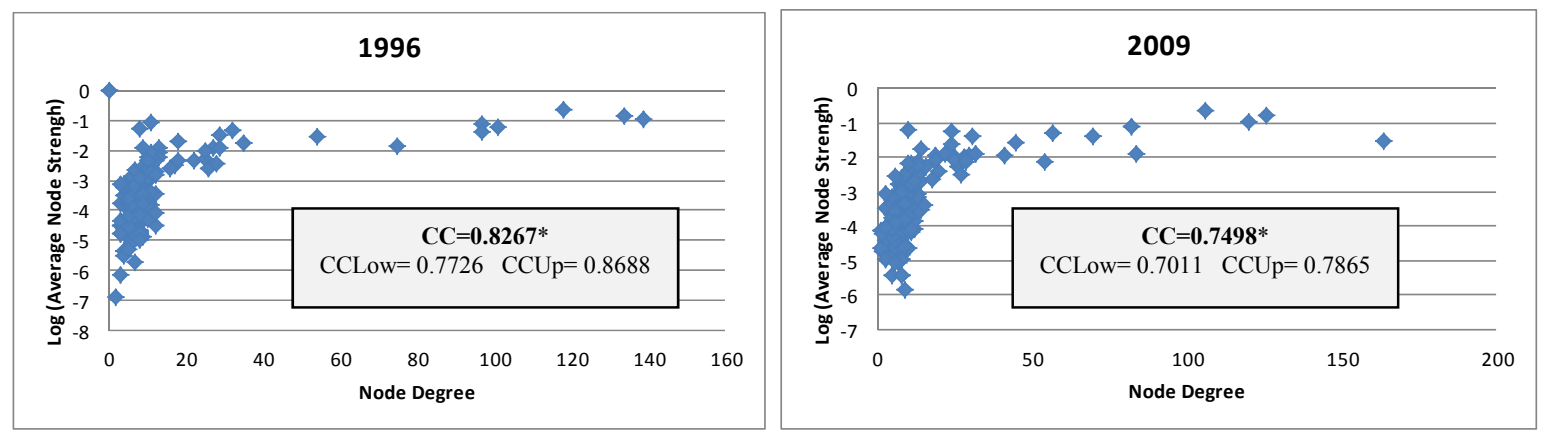

Source: authors' calculation, based on UN COMTRADE. CCLow and CCUp are the correlation coefficients at 5\% and 95\% confidence intervals

Figure 4. Correlations Degree vs Closeness Centrality and Strength vs Random Walk Betweenness Centrality (RWBC) for P\&C WATN, 2009
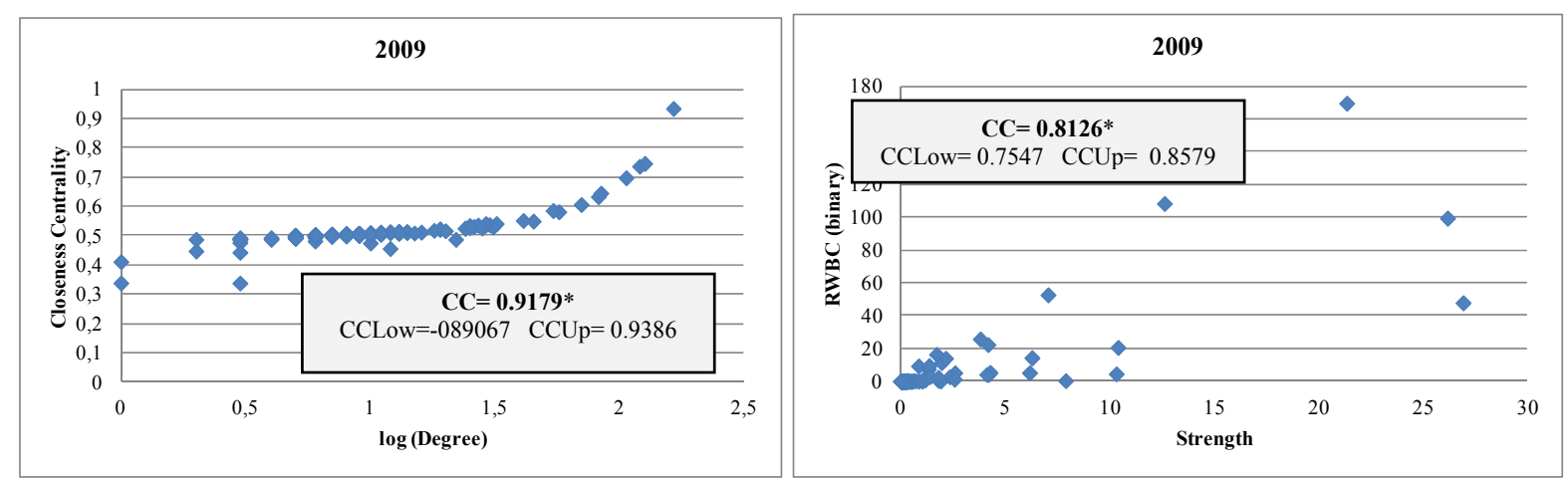

Source: authors' calculation, based on UN COMTRADE. CCLow and CCUp are the correlation coefficients at 5\% and 95\% confidence intervals.

Additionally, the HITS algorithm (Table 2) and the $k$-core indicators analysis (Table 1) suggests that in this centre-periphery structure, regional, local and/or traditional ties play a very important and increasing role in the shaping of the network. The small number of central countries that are at the same time hubs and authorities indicate that these countries not only sell their $\mathrm{P} \& \mathrm{C}$ to those non-producer countries but that there is also an intensive flow of $\mathrm{P} \& \mathrm{C}$ from them towards other (less powerful) P\&C producers in the centre of the network. 
Table 2. Weighted Hub and Authority Centrality in the automotive P\&C

\begin{tabular}{ccccc}
\hline \multirow{2}{*}{ Rank } & \multicolumn{2}{c}{ Weighted Hub Centrality } & \multicolumn{2}{c}{ Weighted Authority Centrality } \\
\cline { 2 - 5 } & 1996 & 2009 & 1996 & 2009 \\
\hline $\mathbf{1}$ & US & CHN & CA & US \\
$\mathbf{2}$ & JP & MX & US & CHN \\
$\mathbf{3}$ & MX & JP & MX & CA \\
$\mathbf{4}$ & CA & CA & UK & JP \\
$\mathbf{5}$ & DE & KO & JP & MX \\
$\mathbf{6}$ & FR & DE & DE & HK \\
$\mathbf{7}$ & IT & US & KO & FR \\
$\mathbf{8}$ & UK & FR & TH & UK \\
$\mathbf{9}$ & ES & IT & FR & DE \\
$\mathbf{1 0}$ & SE & PL & B\&L & KO \\
\hline
\end{tabular}

aArgentina (AR); Australia (AU); Austria (AT); Belgium-Luxembourg (B\&L); Brasil (BR); Canada (CA); China (CHN); Colombia (CO); Czech Rep.(CZ); Denmark (DK); El Salvador (SV); Finland (FI); France (FR); Germany (DE); Honduras $\mathrm{HN}$ ); Hong Kong (HK); Hungary (HU); India (IN); (Indonesia (ID); Israel (IL); Italy (IT); Japan (JP); Malaysia (MY); Mexico (MX); Netherlands (NL); Panama (PA); Philippines (PH); Poland (PL); Portugal (PT); Korea (KO); Romania (RO); Russian F. (RU); Saudi Arabia (SA); Singapore (SG); Slovakia (SK); Slovenia (SI); Spain (ES); Sweden (SE); Switzerland $(\mathrm{CH})$; Thailand (TH); Tunisia (TN); U.A. Emirates (AE); United Kingdom (UK); USA (US) and Venezuela (VE).

Source: authors' calculation, based on UN COMTRADE

The aforementioned structure for the P\&C network is basically repeated for the final goods export network. ${ }^{11}$ This means that only a small group of countries are highly-connected and intense exporters of final goods and those exporters have a highly diverse portfolio of partners (Figure 5). In fact, the most intense P\&C importers and exporters were also the most intense exporters of final goods. And, as expected, we have found that the heaviest P\&C exporters were also the most highly connected countries in the export markets of final goods. However, it seems that the heaviest exporters of final goods do not necessarily have a high number of foreign providers of $\mathrm{P} \& \mathrm{C}$, even though they intensely buy $\mathrm{P} \& \mathrm{C}$ from them.

This parallelism in the configuration of both networks signals an important structural change in the auto network from the nineties to the present. Traditionally, the P\&C sector has been less concentrated (less centralized) than the final assembly sector (Wells and Rawlinson, 1994; Sadler, 1997), but over time, the intense concentration and internationalization process experienced by the component sector in order to be able to source to assembly firms on a world-wide basis has brought the centralization indices of both networks closer. In this sense, we can observe how the $\mathrm{P} \& \mathrm{C}$ network had become even more centralized than the final goods network by 2009 (see Table 1). Nevertheless, P\&C firms are still more geographically scattered in their production and sales patterns than final auto goods companies.

\footnotetext{
${ }^{11}$ No statistically significant differences were found between both networks for most of the structural indicators.
} 
Figure 5. Automotive Final Goods. Outdegree Network (2009)

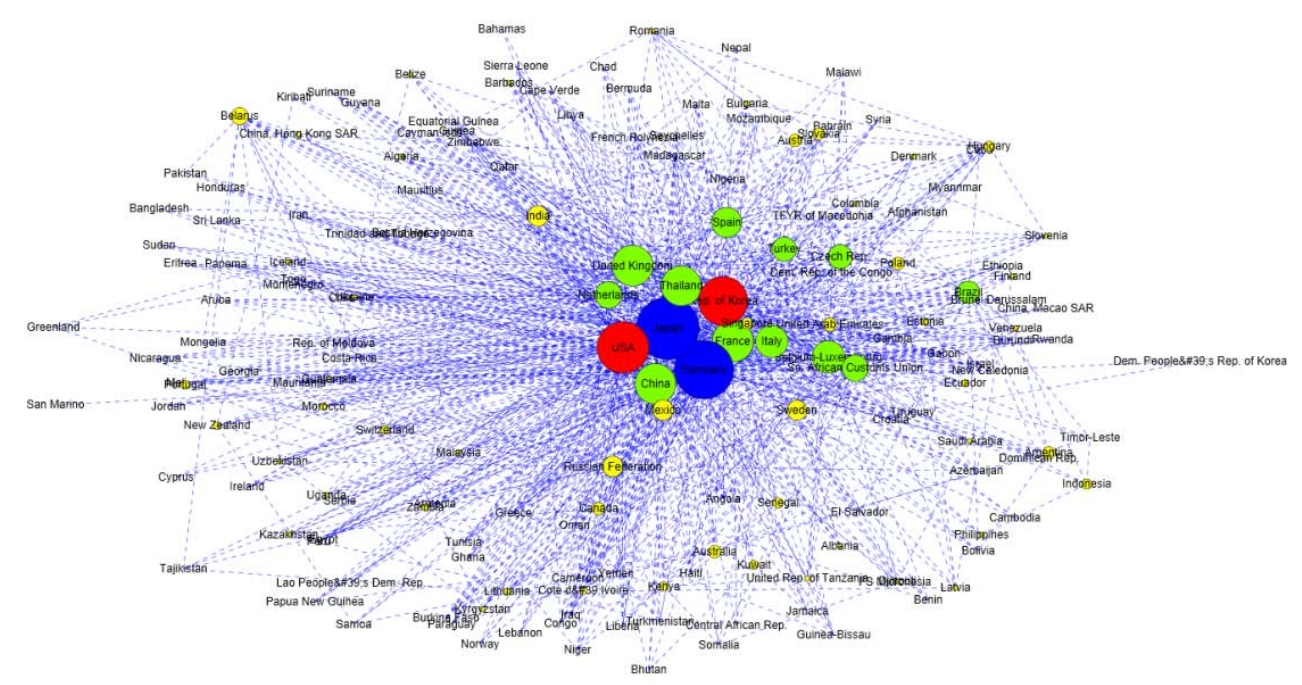

Source: authors' calculation, based on UN COMTRADE using PAJEK. The size of vertices is related to their outdegrees.

The dynamics described so far by the first-order indicators of Social Networks Analysis, in which a centre-periphery structure dominates the WATN, arise mainly from the action of the agglomeration forces. In the next section, we will analyse those centripetal forces that make this structure prevail.

When we examine in more detail the composition of the WATN centre, it seems clear that one of the main agglomeration forces that is acting in its structure is the market effect. The central nucleus of this star-shaped auto network was made up in 1996 of such economies as Japan, Germany and the USA (Table 3). Together with these three, Italy, France, the United Kingdom, Korea ${ }^{12}$, Spain, Belgium-Luxembourg, and the Netherlands were the most central, reachable, and go-between countries in the network. Other important economies in the WATN, located close to large markets were Canada and Mexico, which both had very significant outstrengths in both the $\mathrm{P} \& \mathrm{C}$ and final goods export markets although they were very narrowly linked. All these economies continue to be part of this central nucleus, although together with other countries (see below). Accordingly, in 1996, the densest $k$-core was composed of a European cluster (Belgium-Luxembourg, France, Germany, Italy, Spain, and the United Kingdom) plus Japan and the USA.

One of the reasons why the composition of the WANT centre is made up of those countries is that the intermediate transportation costs in the automotive industry lead automakers to locate close to the end markets. But in addition, the exploitation of the advantages of the international division of labour requires extensive markets, with the market size determining the optimum degree of production fragmentation (Jones et al., 2005). Therefore, the centre-periphery structure is generated by companies' desire for large market

\footnotetext{
${ }^{12}$ When we say Korea, we mean South Korea.
} 
Table 3. The Role of Countries in the International Automotive Production Network (ordered by 2009 outdegree P\&C)

\begin{tabular}{|c|c|c|c|c|c|c|c|c|c|c|c|c|}
\hline & \multicolumn{6}{|c|}{1996} & \multicolumn{6}{|c|}{2009} \\
\hline & \multicolumn{4}{|c|}{ Automotive Parts and Components } & \multicolumn{2}{|c|}{ Automotive Final Goods } & \multicolumn{4}{|c|}{ Automotive Parts and Components } & \multicolumn{2}{|c|}{ Automotive Final Goods } \\
\hline & Outdegree & Outstrength & Indegree & Instrength & Outdegree & Outstrength & Outdegree & Outstrength & Indegree & Instrength & Outdegree & Outstrength \\
\hline China & 23 & 0.95 & 6 & 1.20 & 6 & 0.02 & 160 & 16.99 & 4 & 4.35 & 63 & 0.75 \\
\hline Germany & 123 & 17.86 & 11 & 8.16 & 127 & 22.11 & 114 & 16.53 & 12 & 9.63 & 125 & 25.44 \\
\hline Japan & 130 & 16.75 & 9 & 2.18 & 152 & 18.43 & 113 & 10.07 & 7 & 2.55 & 143 & 17.59 \\
\hline USA & 114 & 20.27 & 4 & 17.79 & 95 & 7.99 & 100 & 9.49 & 6 & 17.42 & 99 & 7.87 \\
\hline Korea & 71 & 0.91 & 4 & 1.54 & 86 & 1.42 & 80 & 5.76 & 4 & 1.28 & 90 & 4.47 \\
\hline France & 89 & 8.06 & 8 & 4.95 & 85 & 7.71 & 72 & 5.60 & 10 & 4.79 & 63 & 6.11 \\
\hline Italy & 90 & 4.73 & 7 & 2.83 & 56 & 3.32 & 61 & 3.73 & 9 & 2.54 & 38 & 2.50 \\
\hline India & 19 & 0.07 & 7 & 0.35 & 16 & 0.04 & 48 & 0.49 & 6 & 1.22 & 16 & 0.15 \\
\hline UK & 94 & 4.39 & 7 & 6.32 & 77 & 5.54 & 45 & 2.35 & 12 & 1.45 & 61 & 3.97 \\
\hline B\&L & 21 & 1.81 & 8 & 4.21 & 36 & 5.28 & 34 & 1.24 & 11 & 2.97 & 39 & 3.68 \\
\hline Hungary & 4 & 0.54 & 8 & 0.23 & 1 & 0.02 & 32 & 2.80 & 9 & 1.38 & 4 & 0.09 \\
\hline Netherlands & 27 & 0.53 & 8 & 2.45 & 32 & 1.10 & 23 & 0.93 & 9 & 1.65 & 27 & 0.39 \\
\hline Poland & 4 & 0.02 & 7 & 0.84 & 0 & 0.00 & 22 & 2.61 & 6 & 1.66 & 6 & 0.79 \\
\hline Spain & 26 & 3.01 & 6 & 4.83 & 38 & 5.84 & 22 & 2.35 & 9 & 3.81 & 34 & 6.05 \\
\hline Brazil & 18 & 0.62 & 9 & 1.56 & 11 & 0.39 & 21 & 1.02 & 9 & 1.31 & 19 & 0.91 \\
\hline UAE & 5 & 0.01 & 11 & 0.41 & 6 & 0.02 & 20 & 0.09 & 9 & 1.26 & 8 & 0.07 \\
\hline Finland & 18 & 0.42 & 7 & 0.48 & 4 & 0.05 & 19 & 0.30 & 7 & 0.54 & 1 & 0.00 \\
\hline Mexico & 5 & 5.35 & 3 & 4.36 & 20 & 4.67 & 18 & 5.86 & 6 & 4.45 & 16 & 5.27 \\
\hline Thailand & 7 & 0.26 & 2 & 1.75 & 3 & 0.00 & 18 & 0.91 & 7 & 1.23 & 60 & 1.58 \\
\hline SACU & 0 & 0.00 & 8 & 0.02 & 0 & 0.00 & 18 & 0.07 & 9 & 0.55 & 26 & 0.26 \\
\hline Turkey & 11 & 0.03 & 7 & 0.78 & 8 & 0.05 & 17 & 0.18 & 12 & 1.61 & 22 & 1.49 \\
\hline Sweden & 43 & 2.90 & 11 & 2.21 & 25 & 0.76 & 15 & 0.79 & 9 & 1.15 & 15 & 0.39 \\
\hline Russia & 19 & 0.25 & 9 & 0.38 & 20 & 0.13 & 15 & 0.29 & 10 & 1.58 & 16 & 0.15 \\
\hline Czech Rep. & 7 & 0.50 & 6 & 0.53 & 12 & 0.14 & 14 & 2.39 & 8 & 1.72 & 21 & 1.68 \\
\hline Singapore & 15 & 0.33 & 10 & 1.37 & 4 & 0.04 & 13 & 0.20 & 6 & 1.11 & 5 & 0.01 \\
\hline Romania & 0 & 0.00 & 4 & 0.13 & 2 & 0.01 & 11 & 0.71 & 9 & 0.69 & 1 & 0.03 \\
\hline Indonesia & 6 & 0.02 & 5 & 0.94 & 0 & 0.00 & 9 & 0.28 & 7 & 0.91 & 4 & 0.05 \\
\hline Austria & 13 & 1.60 & 5 & 1.70 & 4 & 0.33 & 8 & 1.28 & 6 & 1.28 & 6 & 0.47 \\
\hline Canada & 8 & 5.37 & 3 & 10.60 & 8 & 12.28 & 6 & 2.76 & 4 & 5.13 & 6 & 5.44 \\
\hline Portugal & 5 & 0.38 & 6 & 1.09 & 6 & 0.50 & 6 & 0.23 & 7 & 0.63 & 3 & 0.04 \\
\hline Argentina & 4 & 0.28 & 6 & 0.78 & 2 & 0.36 & 4 & 0.19 & 7 & 0.83 & 6 & 0.88 \\
\hline Slovakia & 3 & 0.09 & 7 & 0.12 & 1 & 0.01 & 3 & 0.80 & 7 & 0.99 & 5 & 0.46 \\
\hline
\end{tabular}

Source: authors' calculation, based on UN COMTRADE. 
access in terms of population and purchasing power coupled with a minimization of transportation costs. ${ }^{13}$ In fact, this comparative advantage of some economies, based more on market size than on production costs, is what, according to NEG, should be expected for industries such as this that operate in segmented markets under imperfect competition and with increasing returns to scale and intermediate transportation costs. When these economies are large enough to engage their production, the domestic market is the main consumer; however, when economies attract a more than proportional share of firms, they also become export platforms.

Moreover, the parallelism in the configuration of $\mathrm{P} \& \mathrm{C}$ and final good networks seems to indicate that a second agglomeration force is a consequence of the relational form of the linkages between $\mathrm{P} \& \mathrm{C}$ suppliers and between them and assemblers, caused by the high complexity and modularity of the auto P\&C. In this sense, carmakers' preference for developing local supplier bases through a mixture of encouraging follow-sourcing by major transnational companies in $\mathrm{P} \& \mathrm{C}$, where large suppliers follow their customers' investment abroad, and the upgrading of existing local suppliers (Humphrey and Memodovic, 2003), foster the synchronized structural evolution of the final and P\&C networks. These strategies are also reflected in the increasing role of (regional) hubs in the network that we have seen in the previous section. The increasing role of the central countries as intermediaries in the network is a consequence of the development of central sector-specific knowledge and innovative activity in these economies. Most of the sector's economic activity must pass through their territory because most of the critical technical and engineering tasks are developed within or near them (Sturgeon et al., 2008).

In order to further investigate the results of the development of these input-output linkages within the WATN, and the extent to which it reflects companies' search for the exploitation of spatial heterogeneity among regions in terms of more efficient production through specialization and trade (as classical international trade theories would posit), Table 4 offers the traditional Balassa indexes applied to $\mathrm{P} \& \mathrm{C}$ exports and imports and also to final auto goods exports. For $\mathrm{P} \& \mathrm{C}$ exports, values higher than one indicate specialization in the production and export of these $\mathrm{P} \& \mathrm{C}$. In the case of imports, values higher than one mean specialization in $\mathrm{P} \& \mathrm{C}$ assembly, since imported $\mathrm{P} \& \mathrm{C}$ will necessarily be incorporated into other higher added-value $\mathrm{P} \& \mathrm{C}$ or into final goods. When the import specialization is indeed part of a vertical specialization strategy, meaning that the destination of the final goods is export, then the country also benefits from a comparative advantage in the export of final goods. According to this argument, we can classify countries into three main categories or groups. The first group (G1) is made up of pure producers and exporters of P\&C. The second group (G2) contains those countries that are specialized in labour-intensive assembly tasks. The third group includes those countries that are dually specialized (Kaminsky and Ng, 2001).

\footnotetext{
${ }^{13}$ In this respect, it is important to bear in mind the explanation of the distance puzzle given in Arribas et al. (2011) from the construction of international trade integration indicators; the authors find that the role of distance in bilateral trade, on average, still matters despite the reductions in the cost of trade, although it varies across countries.
} 
This latter behaviour could result from two circumstances. The first possibility is that the country imports $\mathrm{P} \& \mathrm{C}$ that are transformed into other more downstream $\mathrm{P} \& \mathrm{C}$, which are then exported (G3). The second possibility is to export upstream $\mathrm{P} \& \mathrm{C}$, which are transformed into more complex $\mathrm{P} \& \mathrm{C}$ abroad and re-imported from the country for assembly into the final product, which is then exported (G4). Bearing in mind its shortcomings, the analysis of the trade balance can be an indicator of which of the two situations prevails.

Table 4. Specialization of main countries in the automotive sector

\begin{tabular}{|c|c|c|c|c|c|c|c|}
\hline & & \multicolumn{3}{|c|}{1996} & \multicolumn{3}{|c|}{2009} \\
\hline & & \multicolumn{2}{|c|}{$\mathbf{P} \& C$} & \multirow{2}{*}{$\frac{\text { Final Goods }}{\text { Export }}$} & \multicolumn{2}{|c|}{$P \& C$} & \multirow{2}{*}{$\begin{array}{c}\text { Final Goods } \\
\text { Export }\end{array}$} \\
\hline & & Import & Export & & Import & Export & \\
\hline \multirow{3}{*}{ G1 } & Japan & 0.44 & 1.40 & 1.65 & 0.70 & 1.37 & 2.47 \\
\hline & Korea & 0.59 & 0.52 & 0.87 & 0.59 & 1.38 & 1.17 \\
\hline & China & 0.42 & 0.48 & 0.02 & 0.52 & 1.02 & 0.07 \\
\hline \multirow{3}{*}{ G2 } & UK & 1.06 & 0.82 & 1.04 & 1.10 & 0.86 & 1.35 \\
\hline & USA & 1.12 & 1.35 & 0.60 & 1.19 & 0.94 & 0.82 \\
\hline & B\&L & 1.33 & 0.55 & 1.73 & 0.88 & 0.47 & 1.06 \\
\hline \multirow{6}{*}{ G3 } & Hungary & 0.76 & 3.15 & 0.58 & 2.00 & 3.48 & 0.80 \\
\hline & Mexico & 2.01 & 2.40 & 2.20 & 1.72 & 2.42 & 2.27 \\
\hline & Czech Rep. & 1.03 & 1.25 & 0.83 & 1.71 & 2.08 & 1.70 \\
\hline & Poland & 1.20 & 0.63 & 0.70 & 1.43 & 1.78 & 1.10 \\
\hline & Germany & 1.03 & 1.31 & 1.72 & 1.33 & 1.20 & 1.96 \\
\hline & France & 0.89 & 1.27 & 1.20 & 1.04 & 1.16 & 1.26 \\
\hline \multirow{7}{*}{ G4 } & Brazil & 1.42 & 1.89 & 0.67 & 1.14 & 1.83 & 1.39 \\
\hline & Spain & 1.99 & 1.45 & 2.65 & 1.68 & 1.21 & 2.71 \\
\hline & Canada & 2.56 & 1.42 & 3.29 & 1.57 & 1.20 & 2.39 \\
\hline & Sweden & 1.51 & 1.88 & 1.18 & 1.27 & 1.16 & 1.02 \\
\hline & Argentina & 1.46 & 1.53 & 1.77 & 1.97 & 1.07 & 3.58 \\
\hline & Thailand & 1.18 & 0.55 & 0.05 & 1.01 & 1.04 & 1.22 \\
\hline & Turkey & 0.94 & 0.74 & 0.34 & 1.33 & 1.02 & 1.87 \\
\hline
\end{tabular}

Source: authors' calculation based on UN COMTRADE.

In Table 3 we see that Japan was in the mid-nineties and still is a pure producer of P\&C which are destined for both export and domestic assembly. The final automotive goods produced at home are of course very much consumed domestically, but they are also heavily targeted at export. Its industry has followed a clear vertical specialization strategy at the highest technological stages. On the other hand, countries such as the United States and the United Kingdom seem to follow a very different strategy: they are specialized in the assembly of $\mathrm{P} \& \mathrm{C}$, which they mostly import or re-import (the latter is very much the case with the United States), mainly into final goods that they either consume domestically or export. Of course, the large US domestic market absorbs a relatively higher proportion of the final 
national automotive production, although we should bear in mind that this country is the third largest world exporter of automotive final goods. It is also interesting to observe how in the mid-nineties the United States was dual specialized, while today it has lost its comparative advantage as a producer and exporter of $\mathrm{P} \& \mathrm{C}$ and is increasingly focused on the assembly of final goods to be sent abroad. We can also see this effect in the downward movement in the hubs-centrality index ranking (Table 2)

The other prominent countries in the WATN both in 1996 and 2009 show a dual specialization and all of them are also specialized in final exports. It therefore seems that these economies have advantages in all stages of the value chain, and the companies located in these countries follow vertical specialization strategies. However, there are some differences between them. Countries such as Germany, France and Mexico import P\&C, which are either transformed into other more downstream P\&C destined for foreign markets or are assembled into the final product in their territories and then exported. In this sense, Germany's role is remarkable. Not only does it import P\&C to be transformed into higher added-value goods, but it is also the main exporter of final goods, so it plays a prominent role as an assembler. On the other hand, economies such as Spain and Canada, though also dually specialized, show higher advantages in assembly. They export $\mathrm{P} \& \mathrm{C}$ that are transformed into higher added-value $\mathrm{P} \& \mathrm{C}$ abroad and then re-imported for assembly into the final goods, which are then consumed domestically or exported. They can be considered export platforms of final automotive goods.

Once again, we can see how the combination of the market effect and the relational linkages between the different stages of the value chain make countries like the United States, the United Kingdom, Germany, Spain and Canada very powerful assemblers despite not being economies with low labour costs or having, a priori, apparent labour cost advantages in the world economy.

\subsection{Second-order indicators: Dispersion forces}

According to the first-order aggregate network indicators in Table 1, it seems clear that in 2009 the WATN continued showing a clear centre-periphery structure. However, it is also possible to appreciate that the average nearest-neighbor degree (ANND) is much higher than the average node degree and has increased slightly over time. This difference indicates that the central, highly connected countries are increasingly extending those relations towards poorly-connected countries. In other words, the automotive network is gradually expanding around the world, including new countries that traditionally did not use to actively take part in the network.

This is also confirmed by the moderate although gradually disassortative nature of the binary network insofar as the correlation between ANND and node degree is not very high (Figure 6). The directional analysis ratifies this disassortativity. Nevertheless, when the weighted network is considered, the correlation between node strength and the average 
nearest-neighbor strength (ANNS) is negative and increasing but fairly weak in magnitude (Figure 7). This means that partners of countries with intense relationships do not necessarily have intense trade links themselves. In other words, not all countries in the network have strengthened their links to the same degree; only one group of countries has intensified their flows. Additionally, the non-correlation between the node degree and the weighted average nearest-neighbor degree (WANND) indicates that well-connected countries' partners do not necessarily have intense trade links with all their partners. That is to say that what we perceive is an incipient strategy in which by expanding their production networks to new, low-trade countries, companies are trying to take advantage of scale economies and lower labour costs, especially for the most standardized and low added-value $\mathrm{P} \& \mathrm{C}$, while the bulk of $\mathrm{P} \& \mathrm{C}$ is still produced and sold by a small number of central countries. With this strategy, companies are trying to minimize the spatial differentiation for those activities that are common to the whole range of products that they sell and that are concentrated in clustered locations near to the companies' headquarters and traditional large markets. At the same time, they are trying to differentiate their products to better fit their consumers' preferences and minimize transportation costs, so they are choosing to locate some parts of the process close to the final markets.

Figure 6. Correlation between ANND and Node Degree for P\&C WATN (1996 and 2009)

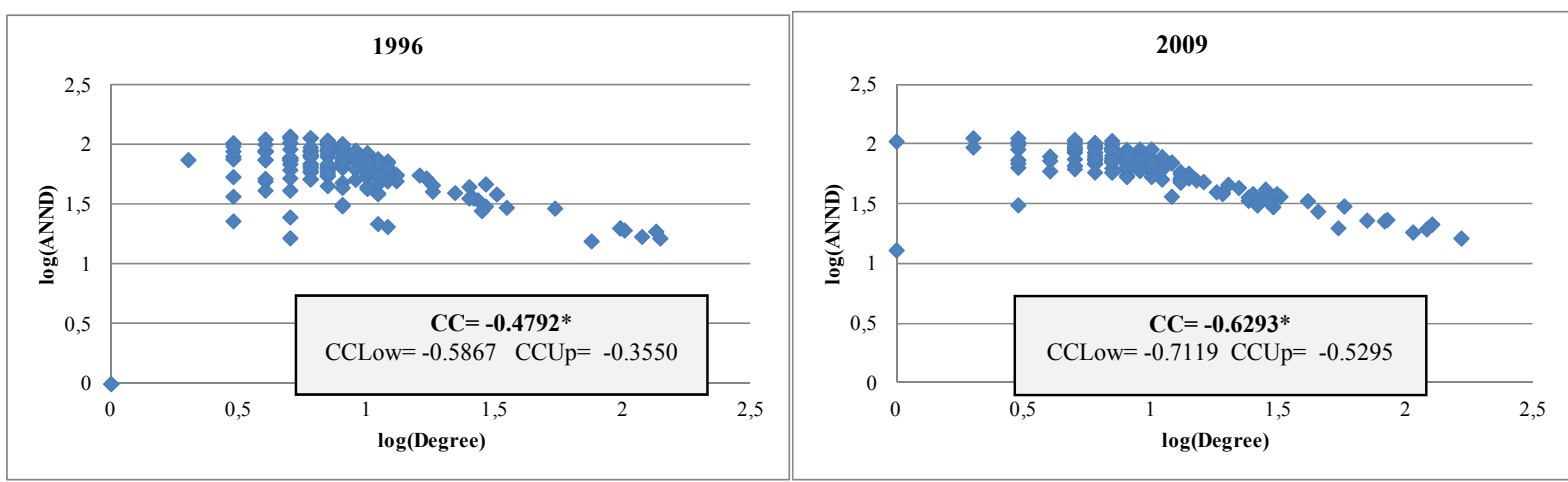

Source: authors' calculation, based on UN COMTRADE. CCLow and CCUp are the correlation coefficients at 5\% and 95\% confidence intervals.

Figure 7. Correlation between ANNS and Node Strength for P\&C WATN (1996 and 2009)

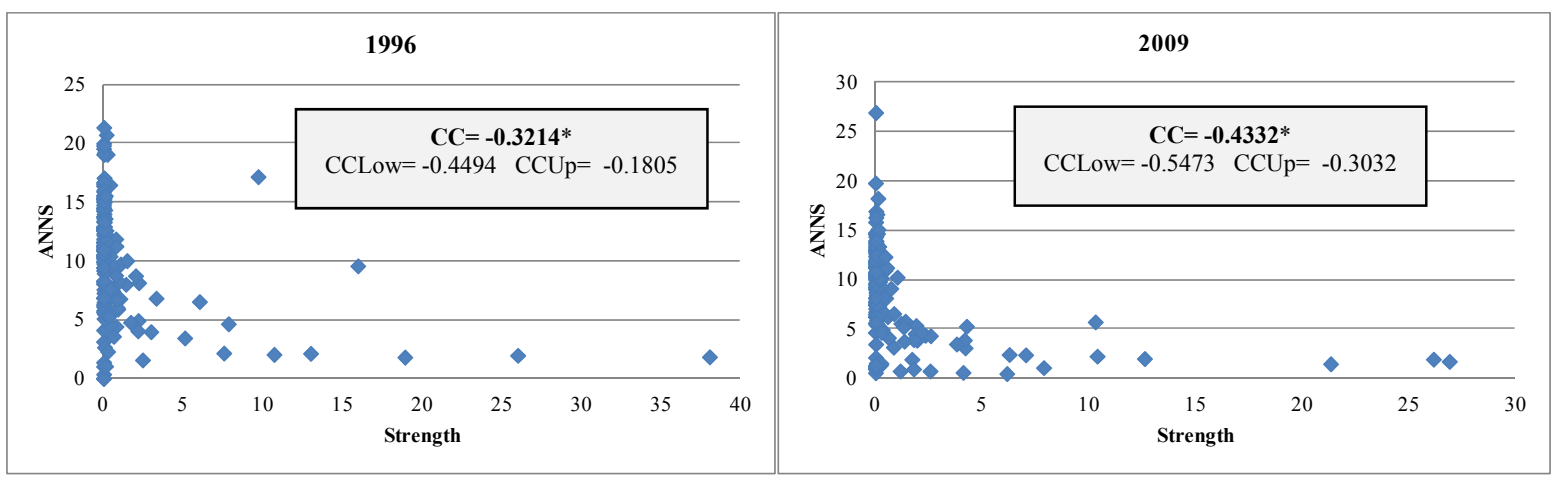

Source: authors' calculation, based on UN COMTRADE. CCLow and CCUp are the correlation coefficients at 5\% and 95\% confidence intervals. 
Therefore, the analysis of the second-order relation measures indicates that even together with dominant agglomeration forces, the search for new and remote markets with high potential in terms of demand that would allow companies to avoid market saturation in traditional markets are acting as a powerful dispersion force. In the next section we analyse these centrifugal forces in more detail.

When we analyse the composition of the WATN centre in 2009 and compare it with that of 1996, we observe that, although the prominent countries in the networks have maintained their importance within the WATN, significant new players have entered that have redistributed the auto market.

In this vein, China had emerged overwhelmingly in the P\&C network centre in 2009: it had risen to the top positions in all centrality indexes. Not only had it increased its links spectacularly over the period but those links were strong enough to overtake Germany in outstrength (see Table 3). It is also worth mentioning the escalating behaviour of Korea. This country was already highly connected in 1996 although its intensity was weak, but by 2009 its numerous trade links had translated into high export intensity. Additionally, some Eastern European countries, such as Hungary, Poland, and the Czech Republic have also gained importance in the $\mathrm{P} \& \mathrm{C}$ export network, forging numerous and intense trade links. Note that Poland and Hungary were among the most important intermediary economies in the network in 2009 and display two of the highest weighted hub-centrality scores (Table 2).

Therefore, in spite of this process of relocation towards new large and/or low-cost peripheral countries and the loss of production and trade flows among some core and traditional peripheral countries, we cannot say that we are witnessing a deindustrialization process in the sector $\grave{a}$ la Kuznets. When firms set up their operations in new places, they rarely abandon their home bases completely; they remain rooted there to serve the home market and to supplement offshore production through exports. Intermediate transportation costs and location hysteresis, plus the weight of history, play a prominent role in keeping companies tied to the same country (or region) for long periods of time. The existence of longstanding regional clusters that try to obtain the maximum agglomeration rents is clear evidence of this. What has happened is that these new groups of countries have joined the old clusters and the latter have created new links with them, expanding the scale and scope of the network. In 2009, some of these countries were part of the densest and most cohesive group of exporters, as revealed by the $k$-core analysis (Table 1 ).

Additionally, we should note that only large (huge in some cases) emerging markets with an intermediate level of development or economies that are very close to and/or integrated in large markets are being included in the more extensive and integrated auto network. In this sense, the market effect has maintained the traditional imbalances in the spatial distribution of the automotive industry. 
This reorganization of the auto market that is balancing agglomeration and dispersion forces is observed in all factorial P\&C networks (Table 5 and 6). Two common dynamics, regardless of factorial intensity, have been observed. The first is an intense transfer of activity from the United States and Japan to new economies, mainly Asian countries. As long as the North American and Asian networks are closely linked, the movement of their respective central countries has resulted in both regional networks experiencing parallel transformations. While this strategy is highly typical of American automakers, which tend to systematically break relational ties after the necessary collaborative engineering work with their suppliers has been accomplished and very frequently open re-bid processes in an effort to lower input costs, it signals a profound change in the strategy of Japanese automotive companies, which have traditionally been highly reluctant to move their production abroad and for whom predatory supplier switching used to be almost unheard of (Sturgeon et al., 2008). In fact, this outsourcing process has taken place in Japan later and less aggressively than among North American and even European carmakers. Nevertheless, in recent years, Japanese companies have been further expanding their already-high local capacity in North America and Europe and have relocated their plants to serve locally China, other South-East Asian countries, and other developing countries (Shimokawa, 2010).

As a result of those movements, over the period analysed, Korea and China have hosted important auto multinationals that have made them pure producers and exporters of P\&C (see Table 4). Both countries are among the five countries with the highest weighted hub-centrality index (Table 2). Korea is also consolidating its position in the global network as an assembler and exporter of final goods, whereas given China's huge domestic market, for the time being most of the P\&C it produces and imports are assembled inside the country and targeted at satisfying its own demand. Nevertheless, the high number of trade links that the country is creating leads us to expect the export market to be a future goal of the assemblers settled in China. Figures for instrength in Table 3 and import specialization indexes (see Table 4) indicate that the two Asian countries (and also Japan) relatively import and re-import very low amounts of components, attaching importance to the domestic component industry, which has traditionally been highly protective (Nag et al., 2007).

The second dynamic is a German-led extension of the European networks mainly towards the new EU members (also to China). Eastern European countries are coming to the fore in the automotive network by transforming imported $\mathrm{P} \& \mathrm{C}$ into other downstream $\mathrm{P} \& \mathrm{C}$, which are either exported directly for assembly abroad or are assembled domestically into final goods and then exported from their territories. This is clearly the strategy of the Czech Republic. Other countries, such as Hungary, mainly transform imported P\&C into higher added-value $\mathrm{P} \& \mathrm{C}$, which are re-exported back for assembly. 
Table 5. Main Destination and Origins of Automotive P\&C. Central Countries in Automotive Network ${ }^{\mathrm{a}}$

\begin{tabular}{|c|c|c|c|c|c|c|c|c|c|c|c|c|c|c|c|c|c|c|c|c|c|c|c|}
\hline \multicolumn{24}{|c|}{ Automotive Total P\&C } \\
\hline \multicolumn{8}{|c|}{ Germany } & \multicolumn{8}{|c|}{ Japan } & \multicolumn{8}{|c|}{ USA } \\
\hline \multicolumn{4}{|c|}{ Exports } & \multicolumn{4}{|c|}{ Import } & \multicolumn{4}{|c|}{ Export } & \multicolumn{4}{|c|}{ Import } & \multicolumn{4}{|c|}{ Export } & \multicolumn{4}{|c|}{ Import } \\
\hline \multicolumn{2}{|c|}{1996} & \multicolumn{2}{|c|}{2009} & \multicolumn{2}{|c|}{1996} & \multicolumn{2}{|c|}{2009} & \multicolumn{2}{|c|}{1996} & \multicolumn{2}{|c|}{2009} & \multicolumn{2}{|c|}{1996} & \multicolumn{2}{|c|}{2009} & \multicolumn{2}{|c|}{1996} & \multicolumn{2}{|c|}{2009} & \multicolumn{2}{|c|}{1996} & \multicolumn{2}{|c|}{2009} \\
\hline UK & $13,0 \%$ & FR & $8,6 \%$ & FR & $12,9 \%$ & $\mathrm{CZ}$ & $10,2 \%$ & US & $37,1 \%$ & $\mathrm{CHN}$ & $20,6 \%$ & US & $35,2 \%$ & $\mathrm{CHN}$ & $43,7 \%$ & CA & $46,3 \%$ & CA & $35,9 \%$ & JP & $28,2 \%$ & MX & $24,8 \%$ \\
\hline FR & $10,1 \%$ & ES & $7,1 \%$ & AT & $12,3 \%$ & AT & $8,8 \%$ & $\mathrm{TH}$ & $9,6 \%$ & US & $20,4 \%$ & $\mathrm{DE}$ & $9,1 \%$ & KO & $9,3 \%$ & MX & $18,5 \%$ & MX & $25,4 \%$ & $\mathrm{CA}$ & $24,0 \%$ & $\mathrm{CHN}$ & $22,9 \%$ \\
\hline$B \& L$ & $8,5 \%$ & UK & $6,8 \%$ & IT & $9,7 \%$ & $\mathrm{HU}$ & $8,5 \%$ & UK & $4,6 \%$ & $\mathrm{TH}$ & $7,0 \%$ & $\mathrm{CHN}$ & $8,4 \%$ & TH & $8,1 \%$ & $\mathrm{JP}$ & $4,6 \%$ & $\mathrm{CHN}$ & $3,3 \%$ & MX & $21,8 \%$ & $\mathrm{CA}$ & $12,4 \%$ \\
\hline ES & $8,2 \%$ & US & $6,7 \%$ & UK & $9,6 \%$ & FR & $8,0 \%$ & ID & $4,2 \%$ & DE & $4,0 \%$ & SE & $6,6 \%$ & US & $7,1 \%$ & $\mathrm{KO}$ & $2,9 \%$ & $\mathrm{DE}$ & $3,2 \%$ & $\mathrm{DE}$ & $5,9 \%$ & JP & $10,7 \%$ \\
\hline US & $7,2 \%$ & CHN & $6,5 \%$ & ES & $7,4 \%$ & PO & $7,8 \%$ & DE & $3,9 \%$ & $\mathrm{KO}$ & $3,7 \%$ & TH & $5,9 \%$ & DE & $6,4 \%$ & DE & $2,3 \%$ & UK & $2,6 \%$ & BR & $2,3 \%$ & $\mathrm{KO}$ & $10,3 \%$ \\
\hline IT & $6,4 \%$ & AT & $5,8 \%$ & JP & $6,3 \%$ & IT & $7,2 \%$ & HK & $3,7 \%$ & $\mathrm{CA}$ & $3,4 \%$ & $\mathrm{PH}$ & $5,7 \%$ & PH & $4,5 \%$ & UK & $2,2 \%$ & JP & $2,1 \%$ & FR & $2,2 \%$ & $\mathrm{DE}$ & $5,6 \%$ \\
\hline AT & $5,8 \%$ & $B \& L$ & $5,3 \%$ & US & $4,5 \%$ & UK & $5,6 \%$ & $\mathrm{CA}$ & $3,5 \%$ & UK & $2,8 \%$ & MY & $3,6 \%$ & ID & $4,4 \%$ & $\mathrm{AU}$ & $2,0 \%$ & $\mathrm{AU}$ & $2,0 \%$ & $\mathrm{CHN}$ & $2,2 \%$ & BR & $1,3 \%$ \\
\hline SE & $5,0 \%$ & IT & $5,2 \%$ & $\mathrm{HU}$ & $4,4 \%$ & CHN & $4,8 \%$ & KO & $3,4 \%$ & MX & $2,6 \%$ & KO & $3,5 \%$ & MY & $2,1 \%$ & BR & $1,6 \%$ & VE & $1,8 \%$ & UK & $2,1 \%$ & UK & $1,2 \%$ \\
\hline $\mathrm{NL}$ & $4,1 \%$ & $\mathrm{CZ}$ & $4,9 \%$ & $\mathrm{CZ}$ & $3,6 \%$ & ES & $4,6 \%$ & SG & $2,8 \%$ & ID & $2,5 \%$ & FI & $3,2 \%$ & FR & $1,8 \%$ & AT & $1,4 \%$ & BR & $1,6 \%$ & KO & $1,6 \%$ & FR & $1,1 \%$ \\
\hline $\mathrm{CH}$ & $2,2 \%$ & PO & $4,7 \%$ & PT & $3,5 \%$ & SK & $3,9 \%$ & $\mathrm{AU}$ & $2,6 \%$ & BR & $2,5 \%$ & UK & $2,9 \%$ & UK & $1,8 \%$ & HK & $1,2 \%$ & FR & $1,6 \%$ & IT & $1,5 \%$ & IT & $1,1 \%$ \\
\hline $\mathrm{PT}$ & $1,9 \%$ & $\mathrm{HU}$ & $3,9 \%$ & $B \& L$ & $3,4 \%$ & JP & $3,3 \%$ & $\mathrm{CHN}$ & $2,4 \%$ & FR & $2,4 \%$ & IT & $2,3 \%$ & MX & $1,5 \%$ & B\&L & $1,2 \%$ & KO & $1,3 \%$ & SE & $0,8 \%$ & $\mathrm{TH}$ & $1,0 \%$ \\
\hline MX & $1,9 \%$ & MX & $3,4 \%$ & NL & $2,7 \%$ & RO & $3,1 \%$ & $B \& L$ & $1,6 \%$ & $\mathrm{AE}$ & $2,0 \%$ & ID & $2,1 \%$ & NL & $1,2 \%$ & FR & $1,2 \%$ & SG & $1,1 \%$ & $\mathrm{TH}$ & $0,7 \%$ & MY & $0,7 \%$ \\
\hline
\end{tabular}

${ }^{a}$ Argentina (AR); Australia (AU); Austria (AT); Belgium-Luxembourg (B\&L); Brazil (BR); Canada (CA); China (CHN); Colombia (CO); Czech Rep.(CZ); Denmark (DK); El Salvador (SV); Finland (FI); France (FR); Germany (DE); Honduras HN); Hong Kong (HK); Hungary (HU); Indonesia (ID); Israel (IL); Italy (IT); Japan (JP); Malaysia (MY); Mexico (MX); Netherlands (NL); Panama (PA); Philippines (PH); Poland (PL); Portugal (PT); Korea (KO); Romania (RO); Russian F. (RU); Saudi Arabia (SA); Singapore (SG); Slovakia (SK); Slovenia (SI); Spain (ES); Sweden (SE); Switzerland (CH); Thailand (TH); Tunisia (TN); U.A. Emirates (AE); United Kingdom (UK); USA (US) and Venezuela (VE).

Source: authors' calculation, based on UN COMTRADE 
Table 6. Parts and Components Automotive Subnetworks

\begin{tabular}{|c|c|c|c|c|c|c|c|c|}
\hline & \multicolumn{4}{|c|}{1996} & \multicolumn{4}{|c|}{2009} \\
\hline & \multicolumn{8}{|c|}{ Mainstream Driven Parts and Components Network } \\
\hline & Outdegree & Outstrength & Indegree & Instrength & Outdegree & Outstrength & Indegree & Instrength \\
\hline China & 32 & 1.94 & 6 & 1.07 & 152 & 13.68 & 5 & 5.19 \\
\hline Germany & 116 & 19.34 & 10 & 8.60 & 114 & 17.89 & 14 & 9.89 \\
\hline Japan & 128 & 18.03 & 8 & 2.78 & 109 & 12.33 & 6 & 2.71 \\
\hline USA & 103 & 19.12 & 8 & 15.30 & 100 & 12.87 & 7 & 13.37 \\
\hline Italy & 89 & 7.37 & 7 & 4.01 & 78 & 5.72 & 10 & 3.33 \\
\hline Korea & 87 & 2.20 & 4 & 1.96 & 72 & 3.39 & 5 & 1.85 \\
\hline France & 94 & 8.07 & 8 & 6.02 & 69 & 5.54 & 10 & 5.27 \\
\hline UK & 94 & 5.87 & 8 & 5.12 & 49 & 3.12 & 9 & 3.73 \\
\hline Belg.\& Lux. & 30 & 2.18 & 8 & 3.18 & 38 & 2.61 & 11 & 3.31 \\
\hline Thailand & 23 & 0.92 & 5 & 1.43 & 32 & 1.80 & 8 & 1.11 \\
\hline Netherland & 35 & 1.80 & 9 & 2.99 & 29 & 1.32 & 10 & 2.25 \\
\hline Poland & 6 & 0.03 & 9 & 0.77 & 24 & 1.89 & 6 & 1.58 \\
\hline Spain & 29 & 2.53 & 5 & 3.00 & 22 & 2.59 & 9 & 2.49 \\
\hline Czech Rep. & 10 & 0.54 & 6 & 0.77 & 17 & 2.64 & 8 & 1.64 \\
\hline Mexico & 7 & 2.42 & 3 & 3.52 & 11 & 3.09 & 6 & 3.41 \\
\hline \multirow[t]{2}{*}{ Canada } & 4 & 3.86 & 2 & 6.95 & 7 & 2.48 & 4 & 4.59 \\
\hline & \multicolumn{8}{|c|}{ Capital Intensive Parts and Components Network } \\
\hline Germany & 120 & 20.52 & 9 & 6.95 & 119 & 24.30 & 11 & 9.60 \\
\hline Japan & 125 & 17.57 & 7 & 1.25 & 113 & 13.32 & 9 & 1.80 \\
\hline China & 7 & 0.12 & 4 & 1.12 & 110 & 4.79 & 4 & 6.01 \\
\hline USA & 101 & 21.90 & 5 & 17.61 & 91 & 10.69 & 6 & 13.88 \\
\hline France & 75 & 10.07 & 7 & 4.80 & 78 & 8.49 & 8 & 4.98 \\
\hline Italy & 80 & 4.53 & 7 & 2.27 & 67 & 4.54 & 8 & 2.66 \\
\hline UK & 89 & 4.00 & 7 & 9.64 & 54 & 1.77 & 8 & 4.25 \\
\hline Korea & 23 & 0.51 & 3 & 1.35 & 45 & 3.33 & 6 & 1.53 \\
\hline Spain & 19 & 3.48 & 5 & 5.54 & 37 & 3.44 & 6 & 5.69 \\
\hline Belg.\& Lux. & 29 & 1.92 & 8 & 4.99 & 34 & 1.74 & 9 & 3.43 \\
\hline Poland & 5 & 0.03 & 6 & 0.56 & 17 & 2.93 & 7 & 2.20 \\
\hline Sweden & 23 & 1.90 & 7 & 2.27 & 17 & 0.84 & 9 & 1.67 \\
\hline Czech Rep. & 8 & 0.38 & 6 & 0.45 & 13 & 3.07 & 7 & 2.11 \\
\hline Mexico & 1 & 2.39 & 4 & 5.38 & 11 & 5.00 & 5 & 5.32 \\
\hline \multirow[t]{2}{*}{ Canada } & 6 & 6.44 & 2 & 12.93 & 3 & 3.17 & 4 & 6.62 \\
\hline & \multicolumn{8}{|c|}{ Labour Intensive Parts and Components Network } \\
\hline China & 17 & 1.85 & 5 & 0.62 & 140 & 14.59 & 5 & 3.27 \\
\hline Germany & 114 & 18.47 & 11 & 10.49 & 108 & 16.19 & 11 & 13.93 \\
\hline Japan & 118 & 11.28 & 8 & 2.84 & 96 & 9.05 & 9 & 2.90 \\
\hline Italy & 99 & 7.91 & 7 & 2.77 & 86 & 6.35 & 9 & 2.64 \\
\hline USA & 90 & 15.21 & 5 & 20.05 & 85 & 7.69 & 5 & 19.29 \\
\hline France & 73 & 6.75 & 7 & 5.74 & 67 & 5.37 & 9 & 5.52 \\
\hline UK & 75 & 4.25 & 8 & 5.66 & 41 & 0.39 & 10 & 4.80 \\
\hline Poland & 7 & 0.62 & 7 & 2.40 & 25 & 4.71 & 7 & 1.94 \\
\hline Belg.\& Lux. & 21 & 3.24 & 8 & 4.81 & 22 & 1.73 & 10 & 3.37 \\
\hline Czech Rep. & 13 & 1.71 & 6 & 0.69 & 21 & 4.45 & 7 & 1.70 \\
\hline Austria & 13 & 1.42 & 8 & 2.33 & 19 & 2.20 & 7 & 1.28 \\
\hline Mexico & 9 & 7.46 & 3 & 3.31 & 18 & 9.00 & 6 & 3.68 \\
\hline Spain & 20 & 2.57 & 5 & 3.71 & 17 & 2.24 & 7 & 2.66 \\
\hline Hungary & 4 & 0.85 & 5 & 0.36 & 13 & 1.61 & 8 & 1.24 \\
\hline Canada & 9 & 6.82 & 3 & 9.54 & 9 & 2.85 & 4 & 4.83 \\
\hline \multirow[t]{2}{*}{ Slovakia } & 1 & 0.07 & 6 & 0.13 & 8 & 2.97 & 10 & 0.94 \\
\hline & \multicolumn{8}{|c|}{ Technology Driven Parts and Components Network } \\
\hline China & 17 & 3.137 & 6 & 1.926 & 156 & 34.326 & 6 & 2.142 \\
\hline Korea & 17 & 0.639 & 5 & 1.715 & 87 & 12.491 & 4 & 0.887 \\
\hline USA & 122 & 18.082 & 5 & 23.299 & 71 & 5.088 & 4 & 22.4107 \\
\hline Germany & 97 & 11.027 & 10 & 8.344 & 59 & 4.149 & 8 & 8.007 \\
\hline Hungary & 7 & 1.880 & 6 & 0.318 & 57 & 7.512 & 8 & 1.444 \\
\hline India & 11 & 0.046 & 8 & 0.068 & 49 & 1.476 & 4 & 1.963 \\
\hline Finland & 43 & 2.425 & 7 & 0.452 & 47 & 2.213 & 5 & 0.923 \\
\hline Japan & 109 & 15.146 & 6 & 3.027 & 45 & 2.187 & 6 & 3.256 \\
\hline France & 72 & 5.123 & 11 & 3.437 & 41 & 1.573 & 9 & 3.913 \\
\hline UK & 77 & 4.422 & 9 & 2.392 & 35 & 3.208 & 10 & 4.097 \\
\hline Sweden & 57 & 7.167 & 10 & 1.176 & 25 & 1.227 & 8 & 0.572 \\
\hline Mexico & 8 & 12.430 & 1 & 3.590 & 24 & 8.151 & 6 & 4.006 \\
\hline Spain & 15 & 2.639 & 6 & 5.501 & 11 & 0.608 & 11 & 3.132 \\
\hline Austria & 8 & 2.699 & 6 & 1.181 & 7 & 2.041 & 9 & 0.942 \\
\hline Poland & 0 & 0.000 & 8 & 0.911 & 7 & 1.728 & 8 & 1.570 \\
\hline Canada & 18 & 3.985 & 3 & 9.025 & 4 & 2.240 & 5 & 3.648 \\
\hline
\end{tabular}


In general, the new countries that have joined the network over the last decade have rapidly migrated from simple labour-intensive $\mathrm{P} \& \mathrm{C}$ to more sophisticated technology-driven P\&C. In consequence, global sourcing has caused the list of top suppliers to become more regionally balanced. However, we have observed how most developed countries, Germany in particular, have kept the production of capital-intensive products at home, which are relatively more complex and tend to have higher transaction costs.

The above analysis also reveals certain dispersion in the final goods network, in the same direction as that for auto $\mathrm{P} \& \mathrm{C}$, with some emerging economies that are increasing their presence in the $\mathrm{P} \& \mathrm{C}$ also doing so in the final goods markets. This is the case with the Czech Republic, Poland and Brazil. However, it should also be noted that countries with a scant presence in $\mathrm{P} \& \mathrm{C}$ markets, such as Turkey and Argentina, are also gaining ground as final exporters. This is a common pathway in the expansion of the auto network: new countries first host assembly activities and then increase their production of auto $\mathrm{P} \& \mathrm{C}$. In this process, in contrast to many other industries, in most emerging countries the agglomeration of the final sector in a particular new country (or region) does not occur because there was a previous concentration of the $\mathrm{P} \& \mathrm{C}$ industry in the same country or region; instead, final assembly is often the first step, while the development of a P\&C sector comes later (Sturgeon and Van Biesebroeck, 2011). The relational linkages and the follow-sourcing strategy in the automotive industry then foster a circular process à la Myrdal (more than in other industries) in which market size and the intermediate transportation costs are the key factors. For this reason, those countries that are geographically close to large existing markets or that are large or rich enough to support vehicle assembly are becoming intermediaries in the production of certain $\mathrm{P} \& \mathrm{C}$ that can be exported to the rest of the world. At the same time, these new peripheral economies offer both growing domestic markets for final automotive products and low-cost production sites as workers, with strong incentives from the installation of new manufacturing companies, become more skilled and earn higher salaries, which is again a market expansion force, at least while the gap in costs between the core and periphery remains sufficiently large (Toulemonde, 2006). 


\section{Concluding Remarks}

In this empirical paper, we have examined the evolution of the spatial distribution of economic activities for the automotive industry in the light of some of the assumptions and results obtained from New Economic Geography. For this purpose, instead of traditional equilibrium models, we have applied the tools of Social Network Analysis and graph theory to international trade flows of 172 countries for the years 1996 and 2009. In the analysis we have also distinguished the $\mathrm{P} \& \mathrm{C}$ auto network and the final auto goods network.

As predicted by the NEG, we have found that the structure and evolution of the world auto trade network is determined by the balance between two types of opposing and mutually reinforcing forces: agglomeration (or centripetal) and dispersion (or centrifugal) forces. Thus we have observed that over time the network has maintained a center-periphery structure in which regional, more than global, clusters have arisen and hubs are becoming increasingly important. We have detected two main agglomeration forces as drivers of this structure. Firstly, a very strong market effect, whereby companies seek access to large and/or rich markets in order to exploit the advantages of the international division of labour and minimize the intermediate transportation costs pertaining to the auto industry. And secondly, the relational form of the linkages between $\mathrm{P} \& \mathrm{C}$ suppliers and between them and the final auto goods assemblers that has fostered the synchronized structural evolution of the final and $\mathrm{P} \& \mathrm{C}$ networks, making both of them more centered.

Furthermore, over time, the companies' search for new and high-potential markets that, simultaneously, offer low production costs, hence enabling them to avoid the market saturation and fierce competition of the traditional market, is acting as a powerful dispersion force, leading the auto network to expand around the world. New countries, such as China, other Asian countries and some Eastern European countries, have entered the central nucleus of the world auto trade network, redistributing the market. However, factors such as transportation costs and location hysteresis are playing a prominent role in keeping companies tied to traditional central countries. Therefore, what has happened is that new countries have joined the old clusters, thus expanding the scale and scope of the network.

As a result, we can conclude that although agglomeration forces clearly prevail in the world auto trade network and spatial imbalance remains, centrifugal forces are expanding the network around new areas. This development is likely to foster a process $a$ la Myrdal that, in turn, will boost the expansion of the auto network in the coming years. 


\section{STATISTICAL APPENDIX}

Table A1. Countries included in the analysis

\begin{tabular}{|c|c|c|c|c|}
\hline Afghanistan & Croatia & Italy & Philippines & Uruguay \\
\hline Albania & Cuba & Jamaica & Poland & USA \\
\hline Algeria & Cyprus & Japan & Portugal & Uzbekistan \\
\hline Angola & Czech Rep. & Kazakhstan & Qatar & Venezuela \\
\hline Argentina & $\begin{array}{l}\text { Dem. People's Rep. of } \\
\text { Korea }\end{array}$ & Kenya & Rep. of Korea & Yemen \\
\hline Armenia & Denmark & Kuwait & Rep. of Moldova & Zambia \\
\hline Aruba & Djibouti & Kyrgyzstan & Romania & Zimbabwe \\
\hline Australia & Dominican Rep. & $\begin{array}{l}\text { Lao People's Dem. } \\
\text { Rep. }\end{array}$ & Russian F. & $\mathrm{SACU}$ \\
\hline Austria & Ecuador & Latvia & Rwanda & \\
\hline Azerbaijan & Egypt & Lebanon & Samoa & \\
\hline Bahamas & El Salvador & Liberia & San Marino & \\
\hline Bahrain & Equatorial Guinea & Libya & Saudi Arabia & \\
\hline Bangladesh & Eritrea & Lithuania & Senegal & \\
\hline Barbados & Estonia & Madagascar & Serbia & \\
\hline Belarus & Ethiopia & Malawi & Serbia-Montenegro & \\
\hline Belgium-Luxembourg & Finland & MY & Seychelles & \\
\hline Belize & France & Mali & Sierra Leone & \\
\hline Benin & Kiribati & Malta & $\mathrm{SG}$ & \\
\hline Bermuda & French Polynesia & Mauritania & SK & \\
\hline Bhutan & FS Micronesia & Mauritius & Slovenia & \\
\hline Bolivia & Gabon & Mexico & Somalia & \\
\hline Bosnia Herzegovina & Gambia & Mongolia & Spain & \\
\hline Brasil & Georgia & Montenegro & Sri Lanka & \\
\hline Brunei Darussalam & Germany & Morocco & Sudan & \\
\hline Bulgaria & Ghana & Mozambique & Suriname & \\
\hline Burkina Faso & Greece & Myannmar & Sweden & \\
\hline Burundi & Greenland & Nepal & Switzerland & \\
\hline Cambodia & Guatemala & Netherlands & Syria & \\
\hline Cameroon & Guinea & New Caledonia & Tajikistan & \\
\hline Canada & Guinea-Bissau & New Zealand & Macedonia & \\
\hline Cape Verde & Guyana & Nicaragua & Thailand & \\
\hline Cayman Isds & Haiti & Niger & Timor-Leste & \\
\hline Central African Rep. & Honduras & Nigeria & Togo & \\
\hline Chad & Hungary & Norway & Trinidad- Tobago & \\
\hline Chile & Iceland & Oman & Tunisia & \\
\hline China & India & Pakistan & Turkey & \\
\hline China, Hong Kong SAR & Indonesia & Panama & Turkmenistan & \\
\hline China, Macao SAR & Iran & Papua New Guinea & Uganda & \\
\hline Colombia & Iraq & Papua New Guinea & U.A. Emirates & \\
\hline Congo & Ireland & Paraguay & United Kingdom & \\
\hline Costa Rica & Israel & Peru & $\begin{array}{l}\text { United Rep. of } \\
\text { Tanzania }\end{array}$ & \\
\hline
\end{tabular}

*SACU: Southern African Custom Union: South Africa, Botswana, Namibia, Swaziland, Lesotho. 
Table A2. Automotive Commodities included in the analysis

\begin{tabular}{|c|c|c|c|c|}
\hline \multirow[b]{2}{*}{ Final Goods } & \multicolumn{4}{|c|}{ Auto Parts and Components } \\
\hline & Mainstream & $\begin{array}{c}\text { Technology } \\
\text { Driven }\end{array}$ & $\begin{array}{l}\text { Labour } \\
\text { Intensive }\end{array}$ & $\begin{array}{l}\text { Capital } \\
\text { Intensive }\end{array}$ \\
\hline 870310 & 700711 & 870600 & 870710 & 870810 \\
\hline 870321 & 700721 & 851993 & 870790 & 870821 \\
\hline 870322 & 700910 & 852520 & 940120 & 870829 \\
\hline 870323 & 830210 & 852721 & 940190 & 870831 \\
\hline 870324 & 830230 & 852729 & 940390 & 870839 \\
\hline 870331 & 870990 & 853641 & 871690 & 870840 \\
\hline 870332 & 400950 & 854430 & 851110 & 870850 \\
\hline 870333 & 681310 & 902910 & 851120 & 870860 \\
\hline 870390 & 681390 & 902920 & 851130 & 870870 \\
\hline 870421 & 731816 & 902990 & 851140 & 870880 \\
\hline 870422 & 732010 & 840734 & 851150 & 870893 \\
\hline 870423 & 732020 & 840820 & 851180 & 870894 \\
\hline 870431 & 842139 & 840731 & 851190 & 870899 \\
\hline 870432 & 848210 & 840732 & 851220 & 840991 \\
\hline 870490 & 848220 & 840733 & 851230 & 840999 \\
\hline 870510 & 848240 & 381900 & 851240 & 870891 \\
\hline 870520 & 848250 & 382000 & 851290 & 870892 \\
\hline 870530 & 841520 & & 853180 & \\
\hline 870540 & 841583 & & & \\
\hline 870590 & 841590 & & & \\
\hline 870210 & 850132 & & & \\
\hline 870290 & 850710 & & & \\
\hline 870120 & 850730 & & & \\
\hline 870130 & 850790 & & & \\
\hline 870110 & 853910 & & & \\
\hline 870190 & 853921 & & & \\
\hline 842710 & 401693 & & & \\
\hline 870410 & 841330 & & & \\
\hline & 841391 & & & \\
\hline & 841430 & & & \\
\hline & 841459 & & & \\
\hline & 842123 & & & \\
\hline & 842131 & & & \\
\hline & 848310 & & & \\
\hline & 840890 & & & \\
\hline & 401110 & & & \\
\hline & 401120 & & & \\
\hline & 401210 & & & \\
\hline & 401220 & & & \\
\hline & 401310 & & & \\
\hline & 401699 & & & \\
\hline & 842549 & & & \\
\hline & 842691 & & & \\
\hline & 843110 & & & \\
\hline
\end{tabular}


Table A3. Definition of Topological Measures

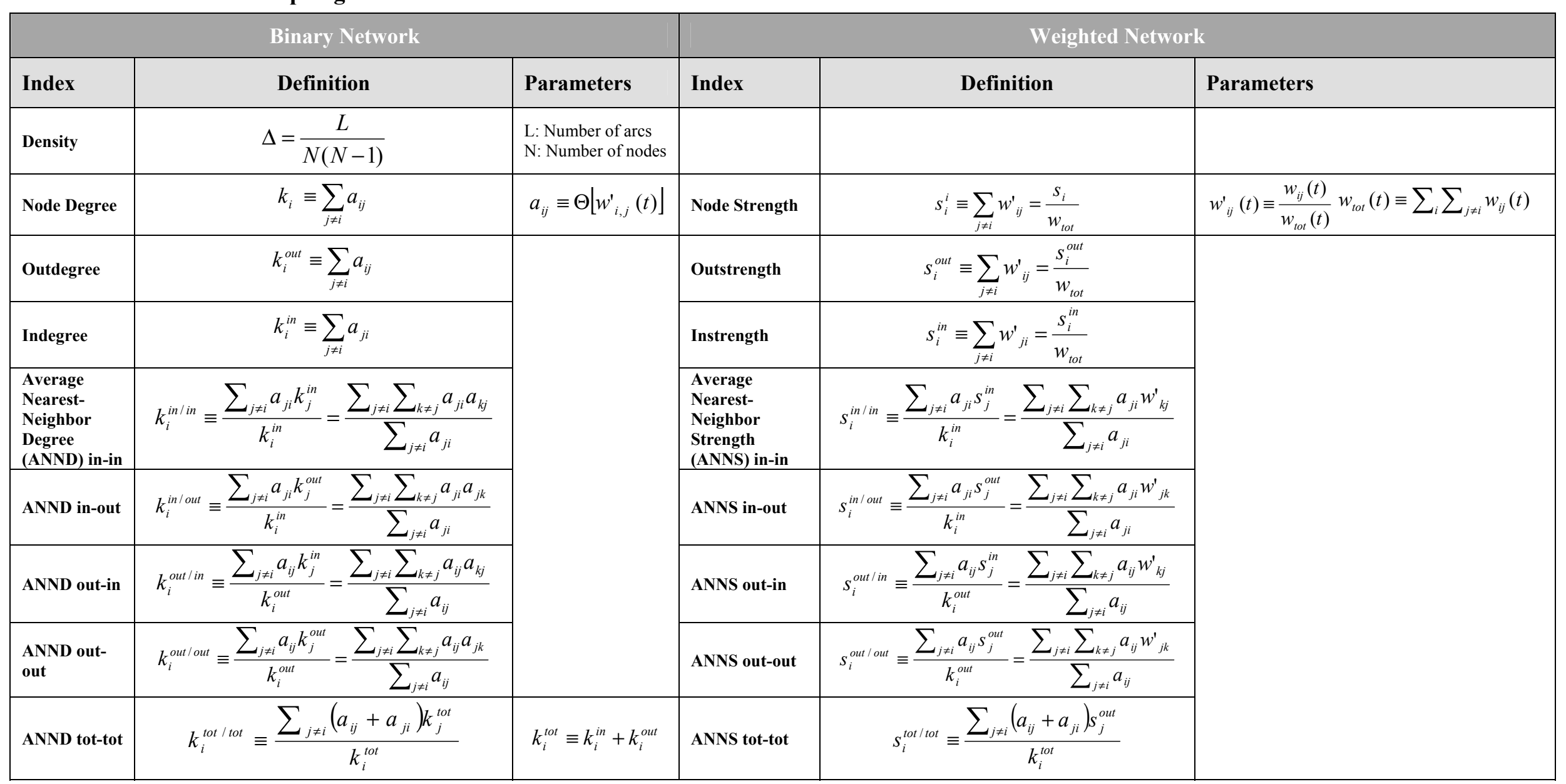


Table A3. Definition of Topological Measures (cont.)

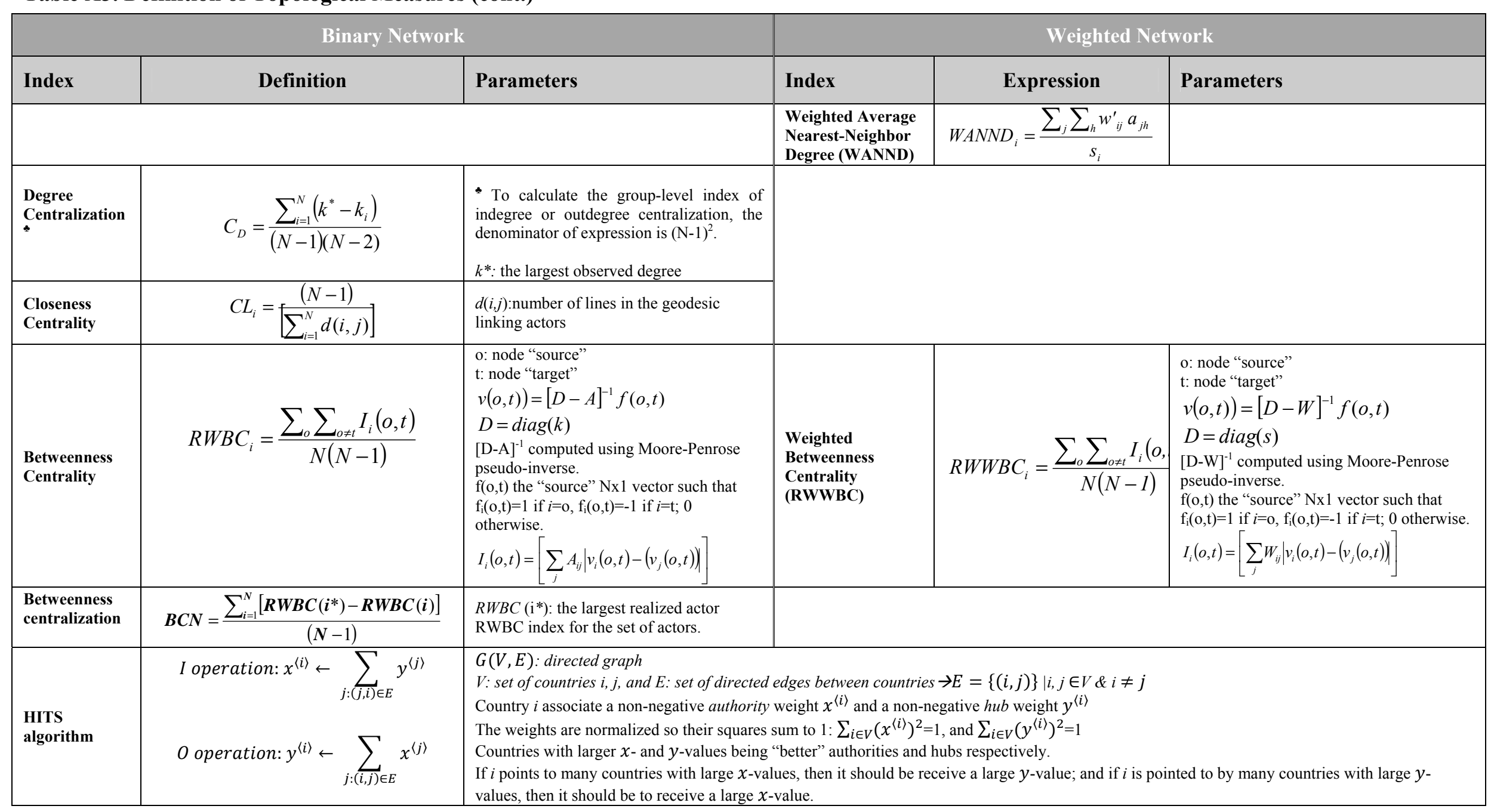




\section{References}

Amighini, A., Gorgoni, S. (2010) The international reorganization of global auto production. Quaderni SEMeQ, 10.

Arribas, I., Pérez, F., Tortosa-Ausina, E. (2011). A new interpretation of the distance puzzle based on geographic neutrality. Economic Geography, 87:335-362.

Arribas, I., Pérez, F., Tortosa-Ausina, E. (2009) Measuring globalization of international trade: theory and evidence. World Development, 37: 127-145.

Athukorala, P. (2009) Global production sharing and Sino-US trade relations. China and World Economy. 17: 39-56.

Athukorala, P. (2011) Production networks and trade patterns in East Asia: Regionalization or Globalization, Asian Economic Papers, 10: 65-95. MIT Press.

Baldwin, R. E., Forslid, R., Martin, Ph., Ottaviano, G. I. P., Robert-Nicoud, F. L. (2003) Economic Geography and Public Policy. Princeton, NJ: Princeton University Press.

Benzi, M., Estrada, E., Klymko, C. (2013) Ranking hubs and authorities using matrix functions. Linear Algebra and its Applications, 438: 2447-2474.

Chinazzi, M., Fagiolo, G., Reyes, J., Schiavo, S. (2013) Post-mortem examination of the international financial network. Journal of Economic Dynamics and Control, forthcoming.

De Benedictis, L., Tajoli, L. (2011) The world trade network. The World Economy, 34: 1417-1454.

Fagiolo, G. (2006) Directed or undirected? a new index to check for directionality of relations in socio-economic networks. Economics Bulletin, 3: 1-12.

Fagiolo, G. (2010) The international-trade network: gravity equations and topological properties. Journal of Economic Interaction and Coordination, 5: 1-25.

Fagiolo, G., Schiavo, S., Reyes, J. (2008). On the topological properties of the world trade web: a weighted network analysis. Physica A: Statistical Mechanics and its Applications, 387: 38683873.

Fisher, E., Vega-Redondo, F. (2006) The linchpins of a modern economy. Working Paper, Cal Poly.

Fujita, M., Thisse, J.F. (2009) New economic geography: An appraisal on the occasion of Paul Krugman's 2008 Nobel Prize. In Economic Sciences, Regional Science and Urban Economics. Elsevier, 109-119.

Garlaschelli, D., Loffredo, M.I. (2005) Structure and evolution of the world trade network. Physica, 355: 138-144.

Humphrey, J., Memedovic, O. (2003) The global automotive industry value chain: what prospects for upgrading for developing countries. Sectoral Studies Series, United Nations Industrial Development Organization, Vienna.

Jones, R. W., Kierzkowski, H., Lurong, C. (2005) What does the evidence tell us about fragmentation and outsourcing?. International Review of Economics and Finance, 14: 305-316.

Kali, R., Reyes J. (2007) The architecture of globalization: A network approach to international economic integration. Journal of International Business Studies, 38: 565-620.

Kali, R., Mendez, F., Reyes J. (2007) Trade structure and economic growth. Journal of International Trade and Economic Development, 16: 245-269.

Kaminski, B., Ng F. (2001) Trade and production fragmentation: Central European Economies in EU networks of production and marketing. Policy Research Working Paper 2611, The World Bank.

Kim, Ch. (2002) Production sharing and comparative advantage: The cases of East Asia and Mexico. Economía Mexicana, XI: 409-430.

Kleinberg, J. (1999) Authoritative sources in a hyperlinked environment. Journal of the ACM , 46: 604-632. 
Krugman, P. R. (1980) Scale economies, product differentiation and the pattern of trade, American Economic Review, 70: 950-959.

Krugman, P. R. (1991) Increasing returns and economic geography. Journal of Political Economy, 99: 483-499.

Krugman, P. R. (1993) On the relationship between trade theory and location theory. Review of International Economics, 1: 110-122.

Krugman, P.R., Venables, A. J. (1995) Globalization and the inequality of nations. The Quarterly Journal of Economics, 110: 857-880.

Krugman, P. R. (2001) Where in the world is the 'New Economic Geography'?. In The Oxford Handbook of Economic Geography, Clark, G.L., Gertler, M.S., Feldman, M.P. (ed.), 49-60.

Nag, B, Banerjee, S., Chatterjee, R. (2007) Changing features of the automobile industry in Asia: comparison of production, trade and market structure in selected countries. Working Paper Series 37, Asia-Pacific Research and Training Network on Trade.

Newman, M. E. J. (2005) A measure of betweenness centrality based on random walks. Social Networks, 27: 39- 54.

Ottaviano, G., Thisse, J.F. (2004) Agglomeration and economic geography. In J. V. Henderson and Thisse, J. F. (eds) Handbook of Regional and Urban Economics, Elsevier, 4: 2563-2608.

Peneder, M. (1999) Intangible investment and human resources. The new taxonomy of manufacturing industries. Working Paper 114, WIFO.

Sadler, D. (1997) Internationalization and specialization in the European automotive components sector: implications for the hollowing-out Thesis. Regional Studies, 33: 109-119.

Shimokawa, K. (2010) Japan and the Global Automotive Industry, Cambridge University Press

Squartini, T., Fagiolo G., Garlaschelli, D. (2011b) Randomizing world trade. Part II. A weighted network analysis. Physical Review E, 84046118.

Sturgeon T.J., Van Bieserbroeck, J., Gereffi, G. (2008) Value chains, networks and clusters: reframing the global automotive industry. Journal of Economic Geography, 8: 297-321.

Sturgeon T.J., Memedovic, O., Van Bieserbroeck, J., Gereffi, G. (2009) Globalisation of the automotive industry: mean features and trends. International Journal of Technological Learning, Innovation and Development, 2: 7-24.

Sturgeon T.J., Van Bieserbroeck, J. (2010) Effects of the crisis on the automotive industry in developing countries: a global value chain perspective. Working Paper 5330, Policy Research.

Sturgeon, T.J., Van Biesebroeck, J. (2011) Global value chains in the automotive industry: an enhanced role for developing countries?. International Journal of Technological Learning, Innovation and Development, 4: 181-205.

Thomas, I. (2002) Transportation networks and the optimal location of human activities: a numerical geography approach. Edward Elgar, Cheltenham (UK).

Toulemonde, E. (2006) Acquisition of skills, labor subsidies, and agglomeration of firms. Journal of Urban Economics, 59: 420-439.

Türkan, K. (2009) Vertical intra-industry trade: an empirical examination of the Austria's auto parts industry. Working Paper 30, FIW.

Wasserman, S., Faust, K. (1994) Social network analysis: methods and applications. Cambridge: Cambridge University Press.

Wells, P., Rawlinson, M. (1994) The new European automobile industry. Basing-stoke: Macmillan Press. 


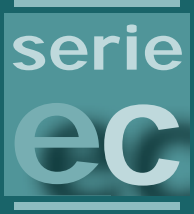

\section{I vie}

Guardia Civil, 22 - Esc. 2, 1음

46020 Valencia - Spain

Phone: +34 963190050

Fax: +34 963190055

Website: http:/ / www.ivie.es

E-mail: publicaciones@ivie.es 